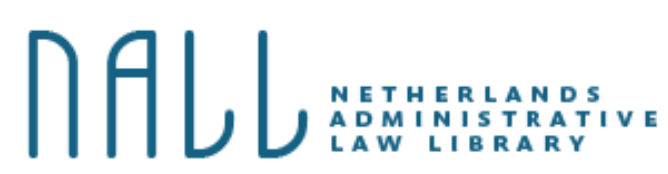

Citeerwijze van dit artikel:

Claartje van Dam, 'De doorwerking van Europese administratieve soft law: in strijd met Nederlandse legaliteit?', NALL 2013, januari-maart, DOI: 10.5553/NALL/.000009

DOI: 10.5553/NALL/.000009

\title{
De doorwerking van Europese administratieve soft law: in strijd met Nederlandse legaliteit?
}

\section{Claartje van Dam}

De doorwerking van Europese administratieve soft law:

in strijd met Nederlandse legaliteit?

\section{Inleiding}

'Dura lex sed lex'. De wet is hard, maar het is nu eenmaal de wet. ${ }^{\mathbf{1}}$ De wet is bindend en dient door allen, door de burgers en door de overheid, te worden gerespecteerd. De wet geeft uitdrukking aan de wil van het volk omdat bij de vaststelling daarvan volksvertegenwoordigers zijn betrokken. De wet komt tot stand via een transparante, vooraf vastgestelde procedure. De wet is kenbaar voor iedereen. Deze eigenschappen maken dat de wet hard mág zijn. De wet is het paradepaardje van het legaliteitsbeginsel, dat waakt voor de binding van de overheid aan de wet. ${ }^{2}$ Het legaliteitsbeginsel heeft tot doel de burgers te beschermen tegen de macht van de overheid. ${ }^{3}$

Niet alle regels zijn in een wet neergelegd. Met wetten alleen kan niet (meer) worden volstaan. Zo stellen Nederlandse bestuursorganen algemene regels op die ze hanteren bij het uitoefenen van discretionaire bevoegdheden of voor de interpretatie van een vage norm. ${ }^{4}$ In Nederland zijn deze regels bekend als 'beleidsregels' of als 'pseudowetgeving'. ${ }^{\mathbf{5}}$

Ook door internationale organisaties worden vaak regels aangenomen die niet in een wet zijn neergelegd. Deze regels worden aangeduid als 'soft law'. Een voorbeeld zijn de geluidsrichtlijnen van de Wereldhandelsorganisatie. ${ }^{\mathbf{6}}$ Soft law komt ook voor in de Europese Unie. 'Europese soft law' heeft verschillende verschijningsvormen. Eén van deze verschijningsvormen is Europese administratieve soft law. Dit zijn gedragsregels die beogen sturing te geven bij de uitlegging of de toepassing van Europese hard law. ${ }^{7}$

\subsection{Vraagstelling}

Europese administratieve soft law beschikt niet over dezelfde eigenschappen als 'dura lex'. ${ }^{8}$ Soft law-handelingen komen niet tot stand volgens een vooraf vastgestelde procedure waarin het Europese parlement een medewetgevende rol heeft. Soft law-handelingen missen in die zin dus democratische legitimatie. ${ }^{9}$ De totstandkoming vindt voornamelijk plaats achter gesloten deuren. Europese administratieve soft law-handelingen zijn vaak niet gepubliceerd. ${ }^{\mathbf{1 0}}$ Toch kunnen van Europese administratieve soft law juridische effecten uitgaan. ${ }^{\mathbf{1 1}}$ In meerdere of in mindere mate kunnen Europese administratieve soft law-handelingen voor de lidstaten een bindende werking hebben. De effecten van de soft law-handelingen werken door in de rechtsordes van de lidstaten. Ze raken niet alleen de autoriteiten van de lidstaten, maar indirect ook de burgers van de lidstaten.

Het doel van dit artikel is om in kaart te brengen op welke wijze Europese administratieve soft 
law in de nationale rechtsorde doorwerkt, om deze doorwerking te beoordelen in het licht van het Nederlandse legaliteitsbeginsel en eventuele knelpunten te inventariseren. Zo nodig kan worden gezocht naar oplossingsrichtingen die de gevonden knelpunten kunnen wegnemen. De volgende vraag staat centraal:

Op welke wijze werkt Europese administratieve soft law door in de nationale rechtsorde, en in hoeverre is deze doorwerking een probleem in het licht van het Nederlandse legaliteitsbeginsel?

\subsection{Plan van aanpak}

De doorwerking van soft law vindt plaats doordat de nationale rechter, wetgever en bestuursorganen Europese administratieve soft law-handelingen volgen, in aanmerking nemen, toepassen of op een andere manier 'gebruiken'. ${ }^{\mathbf{1 2}}$

Om de doorwerking van Europese administratieve soft law in kaart te brengen, bezie ik niet alleen vanuit een top down-benadering welke eisen vanuit de Unie aan de omgang met soft law door nationale autoriteiten worden gesteld (paragraaf twee), maar onderzoek ik ook door middel van een bottom up-benadering hoe daadwerkelijk met Europese administratieve soft law in de Nederlandse rechtspraktijk wordt omgegaan (paragraaf drie). Ik richt mij in het bottom up-onderzoek op de praktijk bij de uitvoering van Europese subsidieregelingen. De reden hiervoor is dat op het terrein van de Europese subsidies veelvuldig Europese administratieve soft law door de Europese Commissie (hierna: Commissie) wordt aangenomen, en dat bovendien de omgang met Europese administratieve soft law op dit terrein nog niet eerder (uitgebreid) in kaart is gebracht. Het bottom-up onderzoek wordt uitgevoerd aan de hand van de rechtspraak van de Afdeling bestuursrechtspraak van de Raad van State (hierna: de Afdeling) en van het College van het Beroep voor het Bedrijfsleven (hierna: CBB of College). Tot slot beoordeel ik de doorwerking van Europese administratieve soft law in het licht van het Nederlandse legaliteitsbeginsel en ga ik op zoek naar mogelijke knelpunten (paragraaf vier). In de vijfde paragraaf worden oplossingsrichtingen gesuggereerd.

\section{Europese administratieve soft law in unierechtelijk perspectief}

Deze paragraaf bestudeert het fenomeen Europese administratieve soft law vanuit het perspectief van de Europese Unie. Na een korte bespreking van de verschillende vormen van Europese administratieve soft law, van de juridische fundering van administratieve soft law en van de context waarin administratieve soft law wordt bestudeerd, komen de lidstaten in beeld. In hoeverre kan Europese administratieve soft law verbindend zijn voor de lidstaten, en welke unierechtelijke eisen worden aan de doorwerking van Europese administratieve soft law gesteld?

\subsection{Europese administratieve soft law}

\subsubsection{De verschillende verschijningsvormen van Europese administratieve soft law}

Onder Europese soft law wordt verstaan gedragsregels die worden vastgelegd in instrumenten waaraan als zodanig geen verbindende kracht is toegekend, maar die desalniettemin bepaalde (indirecte) juridische effecten kunnen hebben in de praktijk. ${ }^{\mathbf{1 3}}$ Europese soft law kent verschillende verschijningsvormen. Eén van deze verschijningsvormen is Europese administratieve soft law.

Europese administratieve soft law vormt een 'paraplubegrip voor instrumenten en handelingen die de Commissie aanneemt met het oog op het geven van sturing aan de uitleg en implementatie van bestaand Unierecht door de lidstaten en haarzelf ${ }^{\mathbf{1 4}}$ Europese administratieve soft law is in documenten met uiteenlopende benamingen neergelegd. De bekendste voorbeelden zijn mededelingen, richtsnoeren en bekendmakingen. In dit artikel zal afwisselend worden gesproken over Europese administratieve soft law en Europese administratieve soft law-handelingen. Bij een soft law-handeling gaat het om een concrete 
handeling (een document) van de Commissie waarin soft law is neergelegd. Europese administratieve soft law refereert meer in het algemeen aan het 'fenomeen' Europese administratieve soft law. Het afwisselend gebruik van deze begrippen dient vooral de leesbaarheid van dit artikel.

Kenmerkend voor administratieve soft law-handelingen is dat zij niet op zichzelf staan, maar gelieerd zijn aan bestaand Unierecht. ${ }^{15}$ De soft law-handelingen vervullen een 'post-law functie'16: zij hebben een aanvullende rol ten opzichte van wetgeving.

Binnen Europese administratieve soft law kan onderscheid gemaakt worden tussen decisoire en interpretatieve soft law. Met interpretatieve soft law beoogt de Commissie aan te geven hoe het Unierecht volgens haar moet worden uitgelegd. ${ }^{17}$ Vage en open begrippen worden met interpretatieve soft law verhelderd en ingekleurd. In het oog moet worden gehouden dat het Hof van Justitie het laatste woord heeft over de interpretatie van het recht van de Europese Unie. ${ }^{18}$

Een soft law-handeling kan worden aangemerkt als 'decisoir' als daarin wordt aangegeven 'hoe de Commissie voornemens is de haar op sommige terreinen gelaten beoordelingsruimte of beleidsvrijheid in te vullen of toe te passen in een concreet geval'. 19

Luijendijk en Senden ontwaren een derde 'tussenvorm' van Europese administratieve soft law die zich recentelijk heeft ontwikkeld. ${ }^{\mathbf{2 0}}$ Het gaat dan om soft law-handelingen waarin de Commissie aan de lidstaten suggesties doet ten aanzien van de omzetting en/of de toepassing van het Europese recht in hun nationale rechtsorde. ${ }^{\mathbf{2 1}}$

Het onderscheid tussen interpretatieve en decisoire soft law-handelingen is niet scherp. Decisoire soft law kan interpretatieve trekken vertonen en andersom kan interpretatieve soft law decisoire karakteristieken hebben. Met de komst van de derde tussenvariant is een (nog) onoverzichtelijke(r) situatie ontstaan die het moeilijk maakt verschillende soft law-handelingen te categoriseren.

\subsubsection{Fundering van Europese administratieve soft law}

Het vage onderscheid tussen de verschillende vormen van soft law is (mede) te verklaren uit het ontbreken van een expliciete juridische fundering van Europese administratieve soft law. Welke instelling mag in welke gevallen administratieve soft law-handelingen aannemen? In welke vorm moeten soft law-handelingen worden gegoten? Volgens welke procedure dienen soft law-handelingen tot stand te komen? De EU-Verdragen zwijgen. ${ }^{\mathbf{2 2}}$

Dat de Verdragen niet voorzien in een totstandkomingsprocedure, betekent dat de betrokkenheid van de Raad van de Europese Unie (hierna: de Raad) of het Europese Parlement (hierna: het Parlement) bij de totstandkoming van administratieve soft law niet is vereist. Administratieve soft law-handelingen missen als zodanig dus democratische legitimatie. Het komt in de praktijk wel voor dat de Raad en het Parlement worden geconsulteerd. ${ }^{\mathbf{2 3}}$ Het ontbreken van procedurevoorschriften zorgt er verder voor dat over de totstandkoming van Europese administratieve soft law weinig bekend is. Wat er precies gebeurt in de radarwerken van de Commissie is voor de buitenwereld (de autoriteiten en de burgers van de lidstaten) vaak niet zichtbaar.

\subsubsection{Europese administratieve soft law in een geïntegreerde rechtsorde}

Europese administratieve soft law is gelieerd aan Europese 'hard law'. Voor de omzetting, uitvoering, toepassing en handhaving van hard law zijn de Europese instellingen afhankelijk van de lidstaten. Alle acties die op nationaal niveau moeten worden ondernomen opdat het Unierecht naar behoren doorwerkt, schaar ik in dit artikel onder het begrip implementatie. ${ }^{\mathbf{2 4}}$ Doordat implementatie van het Unierecht op nationaal niveau plaatsvindt, komt het vaak voor dat één rechtsbetrekking wordt genormeerd door zowel nationaal recht als Europees recht. ${ }^{25}$ Deze vervlechting tussen het Unierecht en het nationale recht maakt dat sprake is van een geïntegreerde rechtsorde en 'gedeeld bestuur'. ${ }^{\mathbf{2 6}}$ Als het bestuur van de lidstaten en het bestuur van de Europese Unie zo sterk met elkaar verweven zijn, 'dat beide componenten nauwelijks meer van elkaar te onderscheiden zijn', is sprake van gemengd bestuur. ${ }^{27}$

Europese administratieve soft law fungeert in de geïntegreerde rechtsorde en speelt zelfs een belangrijke rol in de interactie tussen het EU-niveau en het niveau van de lidstaten. Met 
Europese administratieve soft law kan de Commissie de lidstaten sturen door te laten zien welke koers zij zal varen: hoe zij het EU-recht uit zal leggen, hoe zij van een bevoegdheid gebruik zal maken, of zij verwacht dat de lidstaten van een bevoegdheid gebruik maken. Hierdoor wordt aan de lidstaten rechtszekerheid en duidelijkheid verschaft, en wordt tegelijkertijd de eenheid in de uitleg en de toepassing van Europese hard law bevorderd. Administratieve soft law dient dus een correcte en uniforme interpretatie en toepassing van het Unierecht in de nationale rechtsordes. ${ }^{\mathbf{2 8}}$

\subsection{Europese administratieve soft law en de lidstaten}

\subsubsection{In hoeverre is Europese administratieve soft law verbindend voor de lidstaten?}

Volgens artikel 288 VWEU zijn richtlijnen, verordeningen en besluiten 'verbindend' voor de lidstaten. In de literatuur wordt deze verbindendheid als 'juridische verbindendheid' aangemerkt. Onder juridische verbindendheid wordt verstaan het vermogen van een Europese handeling om uit zichzelf juridische werking te hebben. ${ }^{\mathbf{2 9}}$

De Verdragen kennen aan Europese administratieve soft law geen juridisch verbindend karakter toe. Artikel 288 VWEU bevestigt deze niet-verbindendheid ten aanzien van twee soorten (administratieve) soft law: aanbevelingen en adviezen. Dit betekent echter niet dat van administratieve soft law geen juridisch bindende werking kan uitgaan. ${ }^{\mathbf{3 0}}$

In de eerste plaats kan Europese administratieve soft law een bindende werking hebben als deze soft law inhoudelijk gezien dezelfde karaktereigenschappen heeft als 'hard law'. Het Hof heeft deze 'inhoudelijke lijn' ingezet in de ERTA-uitspraak $\mathbf{3}^{\mathbf{3 1}}$ en in latere uitspraken bevestigd..$^{22}$ Een administratieve soft law-handeling komt inhoudelijk overeen met hard law als de soft law-handeling beoogt juridische regels op te leggen die niet reeds in het bestaande recht besloten liggen. 33 De soft law-handeling is dan onrechtmatig. Het Hof kan de handeling nietig (artikel 263 VWEU) of ongeldig (267 VWEU) verklaren. Zolang de soft law-handeling niet nietig of ongeldig is verklaard, kan de handeling rechtsgevolgen in het leven roepen. ${ }^{\mathbf{3 4}}$ Deze jurisprudentie voorkomt dat administratieve soft law kan worden ingezet als een oneigenlijk wetgevingsinstrument. ${ }^{\mathbf{3 5}}$ Een voorbeeld waarin dit het geval was, is de uitspraak Frankrijk/Commissie. Het Hof verklaart een Mededeling van de Commissie nietig omdat uit de Mededeling verplichtingen voortvloeien waarin door de bepalingen in het Verdrag waaraan de mededeling verbonden is, niet worden wordt voorzien. Deze mededeling komt nagenoeg overeen met een ontwerp van een richtlijn dat geen doorgang heeft kunnen vinden omdat onvoldoende steun bestond in de Raad en het Parlement. ${ }^{36}$

In de tweede plaats kan de bindende werking van een soft law-handeling voortvloeien uit een onderliggende hard law-handeling. ${ }^{\mathbf{3 7}}$ Deze hard law-handeling kan de vorm hebben van een specifieke samenwerkingsplicht of van een specifieke secundairrechtelijke rechtsgrondslag. In het geval van een specifieke samenwerkingsplicht is alleen sprake van een bindende werking als de soft law-handeling ook is aanvaard door de lidstaat. De vorm en mate van de bindende werking is overigens niet altijd hetzelfde. Deze verschillen naar gelang de aard en het karakter van de hard law-handeling.

Het (bekende) voorbeeld van een bepaling waarin een specifieke samenwerkingsplicht is neergelegd is artikel 108 lid 1 VWEU dat bepaalt dat de Commissie tezamen met de lidstaten staatssteunregelingen aan een voortdurend onderzoek onderwerpt. In het arrest IJssel-Vliet bepaalt het Hof dat richtsnoeren die op artikel 88 EG-Verdrag (thans artikel 108 lid 1 VWEU) zijn gebaseerd voor Nederland 'bindende werking' hebben. ${ }^{\mathbf{3 8}}$ Nederland is daarom 'gehouden de richtsnoeren toe te passen'. Het Hof leidt deze bindende werking niet alleen af uit de samenwerkingsplicht, maar ook uit het feit dat Nederland de richtsnoeren heeft aanvaard. In het arrest Commissie/Duitsland wordt aanvaarding afgeleid uit de omstandigheid dat de lidstaat betrokken is geweest bij de totstandkoming van de richtsnoeren en ze heeft goedgekeurd. ${ }^{39}$ Volgens Van den Brink suggereert deze jurisprudentie dat van aanvaarding geen sprake is als de lidstaat de soft law-handeling in de praktijk toepast. Er moet sprake zijn van een uitdrukkelijke goedkeuring. ${ }^{40}$

Tot nog toe heeft het Hof het bestaan van bindende werking op grond van een samenwerkingsplicht en aanvaarding alleen aangenomen op het gebied van het 
staatssteunrecht. Uit de algemene bewoordingen van het Hof zou kunnen worden opgemaakt dat deze jurisprudentielijn naar andere gebieden kan worden doorgetrokken. Ik zou hier echter niet zonder meer vanuit willen gaan. Het staatssteunrecht is namelijk een uniek onderdeel van het Europese recht. Alleen staatssteunmaatregelen die verenigbaar zijn met de gemeenschappelijke markt worden toegelaten door de Commissie, die de exclusieve bevoegdheid heeft om de verenigbaarheid van de maatregelen te toetsen. ${ }^{\mathbf{4 1}} \mathrm{Bij}$ de effectuering van het staatssteunrecht is een nauwe samenwerking tussen de Commissie en de lidstaten noodzakelijk ${ }^{4^{2}}$ Als staatssteun onrechtmatig blijkt te zijn verstrekt, moet deze door de lidstaat bij de ontvanger worden teruggevorderd omdat dan de vrije mededinging in gevaar komt. Het is daarom van groot belang dat de lidstaat 'in de pas' loopt met de Commissie, en ook de soft law-handelingen die betrekking hebben op steunverlening in acht neemt. Het is dus aannemelijk dat dit specifieke karakter van het staatssteunrecht een rol speelt in de overweging van het Hof om een bindende werking van soft law-handelingen aan te nemen.

Bij de vraag of de jurisprudentielijn inzake de samenwerkingsplicht en aanvaarding naar een ander rechtsgebied kan worden doorgetrokken, zou daarom de aard van het andere rechtsgebied in ogenschouw moeten worden genomen. Relevant is dan of het rechtsgebied overeenkomsten vertoont met of verwant is aan het staatssteunrecht. Overigens, als de jurisprudentielijn naar andere rechtsgebieden kan worden doorgetrokken, is mijn verwachting dat de aanwezigheid van een samenwerkingsplicht en aanvaarding niet in alle gevallen tot dezelfde vorm en mate van bindende werking leidt als het geval is in het staatssteunrecht. De samenwerkingsplicht in het staatssteunrecht heeft een Verdragsrechtelijke basis. ${ }^{\mathbf{4 3}}$ Als de samenwerkingsplicht in secundair Unierecht is gelegen, lijkt het voor de hand te liggen dat deze plicht een minder 'nauwe' samenwerking vereist. Het gematigder karakter van de plicht tot samenwerking kan doorwerken in de mate van de bindende werking die de soft law-handeling genereert.

Het bestaan van een bindende werking van een soft law-handeling kan, naast uit een samenwerkingsplicht in combinatie met aanvaarding, ook voortvloeien uit een specifieke grondslag in secundair EU-recht die voorziet in de aanname van administratieve soft law. Vaak is dan in de secundairrechtelijke regeling aangegeven in hoeverre een lidstaat de administratieve soft law-handeling in acht moet nemen.

\subsubsection{Europese eisen ten aanzien van de doorwerking van Europese administratieve soft law in de nationale rechtsorde}

Hiervoor is uiteengezet dat van Europese administratieve soft law een bindende werking kan uitgaan. Daarmee is echter nog niet duidelijk hoe de nationale bestuursorganen, wetgever, en rechter met specifieke administratieve soft law-handelingen behoren om te gaan. In deze paragraaf bezie ik welke eisen door het Hof van Justitie, de Europese regelgeving en de Europese Commissie aan de omgang met Europese administratieve soft law worden gesteld.

\section{Europese administratieve soft law en de nationale wetgever}

De wetgever is in beginsel niet verplicht om tot omzetting van Europese administratieve soft law-handelingen over te gaan. Uit artikel 291 VWEU volgt immers dat de lidstaten alle maatregelen van intern recht nemen die nodig zijn ter uitvoering van de juridische bindende handelingen van de Unie (cursivering door mij).44

Toch zal de wetgever soms actie moeten ondernemen. Dit is bijvoorbeeld het geval als de nationale regeling goedkeuring behoeft van de Europese Commissie en de Europese Commissie verlangt dat deze regeling in overeenstemming is met bijvoorbeeld aangenomen richtsnoeren. ${ }^{45}$ Ook als het gaat om soft law die samenhangt met secundaire wetgeving die moet worden omgezet in nationale wetgeving (het gaat dan dus om richtlijnen), kan van de wetgever worden verlangd bij de omzetting van de richtlijn de soft law-handeling in aanmerking te nemen. Een voorbeeld is de Kaderrichtlijn voor elektronische communicatienetwerken en -diensten. ${ }^{46}$ In deze Kaderrichtlijn is neergelegd dat de nationale regelgevende instanties zoveel mogelijk rekening houden met de betreffende richtsnoeren. Volgens Luijendijk en Senden moet deze instructie zo worden gelezen dat de wetgever niet verplicht is de aanbevelingen te volgen, maar dat afwijking daarvan wel gemotiveerd moet 
worden. ${ }^{47} \mathrm{Er}$ is dus sprake van een 'gematigd' bindende werking. Steun voor deze lezing kan worden gevonden in de Friesland Coberco Dairy Foods-uitspraak die hierna zal worden besproken. ${ }^{48}$

\section{Europese administratieve soft law en de nationale bestuursorganen}

In de praktijk hanteert de Commissie het comply or explain-principle. ${ }^{49}$ Zonder onderscheid te maken naar de aard van administratieve soft law-handeling, gaat de Commissie ervan uit dat afwijking van soft law gemotiveerd moet worden. Uit de rechtspraak van het Hof kan echter geen algemene verplichting voor bestuursorganen worden afgeleid om met administratieve soft law-handeling rekening te houden.

In de uitspraak IJssel-Vliet waarin het Hof een bindende werking aannam op grond van een samenwerkingsplicht en aanvaarding overweegt het Hof dat 'het Koninkrijk der Nederlanden gehouden is de richtsnoeren toe te passen, wanneer hij een beslissing neemt over een aanvraag om steun voor de bouw van een vissersvaartuig'. ${ }^{\mathbf{5}}$ Gezien de gebezigde terminologie gehoudendheid tot het toepassen van de soft law - lijkt het Hof weinig ruimte te laten voor (gemotiveerde) afwijking. Ik zou daarom willen spreken van een strikt of sterk bindende werking. Zelfs de bewoordingen in de richtsnoeren die in de zaak IJssel-Vliet centraal staan, zijn dwingend..$^{\mathbf{1}}$ De discretionaire ruimte van de lidstaat is zo volledig ingevuld. Zouden in de soft law-handelingen geen of minder dwingende bewoordingen worden gebruikt, dan behoudt de lidstaat nog enige bewegingsruimte.

Ten aanzien van een soft law-handeling die een grondslag heeft in secundaire wetgeving geldt dat de in de richtlijn gebezigde bewoordingen een indicatie vormen voor de wijze waarop bestuursorganen met deze handeling om moeten gaan. Het is dan steeds de vraag wat met de gebruikte bewoordingen wordt bedoeld. Wat betekent het bijvoorbeeld als een verordening zegt dat bestuursorganen 'rekening moeten houden' met soft law-handelingen? Deze vraag was aan de orde in de Friesland Coberco Dairy Foods-uitspraak. Artikel 504 lid 4 van de douaneuitvoeringsverordening zegt dat de nationale douaneautoriteiten 'rekening houden met' de conclusies van het Comité douanewetboek. Volgens het Hof volgt uit deze bepaling niet dat de conclusies van het Comité voor de douaneautoriteiten een dwingend karakter hebben. De bepaling moet zo worden geïnterpreteerd dat de autoriteiten van de conclusies mogen afwijken 'mits zij hun beslissingen in dit opzicht motiveren'. ${ }^{\mathbf{2}}$

\section{Europese administratieve soft law en de nationale rechter}

In de Grimaldi-uitspraak, waar het gaat om aanbevelingen die ten opzichte van de lidstaten geen bindende gevolgen beogen, $\mathbf{5 3}$ beklemtoont het Hof dat deze aanbevelingen 'niet kunnen worden geacht geen enkel rechtsgevolg te hebben'. De nationale rechterlijke instanties zijn 'gehouden de aanbevelingen bij de oplossing van de bij hen aanhangige geschillen in aanmerking te nemen, met name wanneer deze duidelijkheid verschaffen over de uitlegging van nationale bepalingen die ter uitvoering ervan zijn vastgesteld of wanneer zij bedoeld zijn om dwingende communautaire bepalingen aan te vullen'.54

Uit de Grimaldi-uitspraak volgt dat de nationale rechter de soft law-handelingen niet zomaar naast zich neer mag leggen. Hij is echter niet gehouden de soft law-handelingen strikt toe te passen of nationale bepalingen conform de soft law-handeling te interpreteren, maar is slechts gehouden de soft law-handelingen 'in aanmerking te nemen'. Administratieve soft law vormt dus een verplicht hulpmiddel voor de rechter bij het vinden van een oplossing voor het geschil.55

Men kan zich afvragen of de overweging van het Hof alleen voor aanbevelingen, of ook voor andere vormen van soft law geldt. In de literatuur wordt in het algemeen aangenomen dat de Grimaldi-uitspraak ook geldt voor administratieve soft law-handelingen met andere benamingen. ${ }^{\mathbf{5}}$ Dit lijkt mij juist. Deze lezing sluit aan bij de praktijk van het Hof om handelingen naar hun inhoud te beoordelen, en niet naar het 'jasje' waarin ze zijn gestoken. ${ }^{\mathbf{5 7}}$ De Grimaldi-uitspraak heeft betrekking op aanbevelingen die ten opzichte van de lidstaten geen bindende gevolgen beogen. Hoe moet de rechter omgaan met soft law-handelingen die (via een onderliggende hard law-bepaling) wel bindende gevolgen beogen voor een lidstaat? A- 
contrario redenerend kan uit de Grimaldi-uitspraak worden opgemaakt dat een nationale rechter verplicht is het nationale overheidshandelen aan deze soft law-handelingen te toetsen en het nationale recht in overeenstemming met de soft law-handeling uit te leggen. ${ }^{58}$ Een 'soft law-conforme uitleg' is echter niet mogelijk als dat betekent dat het nationale recht contra legem moet worden uitgelegd. Dit is immers in strijd met het rechtszekerheidsbeginsel. ${ }^{\mathbf{9}}$ Het lijkt ook niet aannemelijk dat de rechter in zo een situatie de soft law-handeling direct moet toepassen en de nationale bepaling buiten toepassing moet laten, zeker niet als de burger daar de dupe van is. Soft law-handelingen zijn 'tertiair Unierecht' en hebben niet uit zichzelf het vermogen om voorrang te hebben boven het nationale recht. Bovendien zou ook dan het beginsel van rechtszekerheid in gevaar zou komen, omdat soft law-handelingen vaak niet worden gepubliceerd. ${ }^{\mathbf{6 0}}$

\section{Conclusie}

Uit de bespreking van de unierechtelijk eisen die worden gesteld aan de doorwerking van Europese administratieve soft law in de nationale rechtsorde, komt naar voren dat soft lawhandelingen die geen bindende werking genieten op grond van een samenwerkingsplicht of op grond van een secundairrechtelijke rechtsgrondslag, toch op grond van de Grimaldirechtspraak en de comply or explain-praktijk van de Commissie een bindende werking genereren. Op grond van de Grimaldi-rechtspraak is de soft law-handeling voor de rechter een verplicht hulpmiddel bij het vinden van een oplossing voor het geschil. De comply or explainpraktijk van de Commissie zorgt ervoor dat bestuursorganen niet zomaar van een soft lawhandeling kunnen afwijken: ook zij moeten de handeling dus in aanmerking nemen. Deze vormen van bindende werking hebben niet een strikt, maar een gematigd karakter: het bestuur en de rechter moeten met de soft law-handeling rekening houden, maar behoeven deze niet per se strikt te volgen.

\subsection{Conclusie}

In deze paragraaf is het fenomeen Europese administratieve soft law vanuit een unierechtelijk perspectief verkend. Europese administratieve soft law heeft geen uitdrukkelijke basis in de Verdragen en is niet juridisch verbindend. Desondanks kan van administratieve soft lawhandelingen een bindende werking uitgaan op grond van een samenwerkingsplicht in combinatie met aanvaarding, of op grond van een secundairrechtelijke rechtsgrondslag. Ook als een samenwerkingsplicht of secundairrechtelijke rechtsgrondslag ontbreekt, dienen nationale autoriteiten soft law-handelingen niet zomaar in de wind slaan. Volgens de Grimaldirechtspraak van het Hof en de comply or explain-praktijk van de Commissie dienen de nationale rechter en de bestuursorganen met de soft law-handeling rekening te houden.

\section{Europese administratieve soft law en de nationale wetgever}

De wetgever is in beginsel niet verplicht om tot omzetting van Europese administratieve soft law-handelingen over te gaan. Uit artikel 291 VWEU volgt immers dat de lidstaten alle maatregelen van intern recht nemen die nodig zijn ter uitvoering van de juridische bindende handelingen van de Unie (cursivering door mij). ${ }^{\mathbf{1}}$

Toch zal de wetgever soms actie moeten ondernemen. Dit is bijvoorbeeld het geval als de nationale regeling goedkeuring behoeft van de Europese Commissie en de Europese Commissie verlangt dat deze regeling in overeenstemming is met bijvoorbeeld aangenomen richtsnoeren. ${ }^{\mathbf{6 2}}$ Ook als het gaat om soft law die samenhangt met secundaire wetgeving die moet worden omgezet in nationale wetgeving (het gaat dan dus om richtlijnen), kan van de wetgever worden verlangd bij de omzetting van de richtlijn de soft law-handeling in aanmerking te nemen. Een voorbeeld is de Kaderrichtlijn voor elektronische communicatienetwerken en -diensten. ${ }^{\mathbf{6 3}}$ In deze Kaderrichtlijn is neergelegd dat de nationale regelgevende instanties zoveel mogelijk rekening houden met de betreffende richtsnoeren. Volgens Luijendijk en Senden moet deze instructie zo worden gelezen dat de wetgever niet verplicht is de aanbevelingen te volgen, maar dat afwijking daarvan wel gemotiveerd moet worden. ${ }^{64}$ Er is dus sprake van een 'gematigd' bindende werking. Steun voor deze lezing kan 
worden gevonden in de Friesland Coberco Dairy Foods-uitspraak die hierna zal worden besproken. ${ }^{65}$

\section{Europese administratieve soft law en de nationale bestuursorganen}

In de praktijk hanteert de Commissie het comply or explain-principle. ${ }^{\mathbf{6 6}}$ Zonder onderscheid te maken naar de aard van administratieve soft law-handeling, gaat de Commissie ervan uit dat afwijking van soft law gemotiveerd moet worden. Uit de rechtspraak van het Hof kan echter geen algemene verplichting voor bestuursorganen worden afgeleid om met administratieve soft law-handeling rekening te houden.

In de uitspraak IJssel-Vliet waarin het Hof een bindende werking aannam op grond van een samenwerkingsplicht en aanvaarding overweegt het Hof dat 'het Koninkrijk der Nederlanden gehouden is de richtsnoeren toe te passen, wanneer hij een beslissing neemt over een aanvraag om steun voor de bouw van een vissersvaartuig'. ${ }^{67}$ Gezien de gebezigde terminologie gehoudendheid tot het toepassen van de soft law - lijkt het Hof weinig ruimte te laten voor (gemotiveerde) afwijking. Ik zou daarom willen spreken van een strikt of sterk bindende werking. Zelfs de bewoordingen in de richtsnoeren die in de zaak IJssel-Vliet centraal staan, zijn dwingend. ${ }^{68}$ De discretionaire ruimte van de lidstaat is zo volledig ingevuld. Zouden in de soft law-handelingen geen of minder dwingende bewoordingen worden gebruikt, dan behoudt de lidstaat nog enige bewegingsruimte.

Ten aanzien van een soft law-handeling die een grondslag heeft in secundaire wetgeving geldt dat de in de richtlijn gebezigde bewoordingen een indicatie vormen voor de wijze waarop bestuursorganen met deze handeling om moeten gaan. Het is dan steeds de vraag wat met de gebruikte bewoordingen wordt bedoeld. Wat betekent het bijvoorbeeld als een verordening zegt dat bestuursorganen 'rekening moeten houden' met soft law-handelingen? Deze vraag was aan de orde in de Friesland Coberco Dairy Foods-uitspraak. Artikel 504 lid 4 van de douaneuitvoeringsverordening zegt dat de nationale douaneautoriteiten 'rekening houden met' de conclusies van het Comité douanewetboek. Volgens het Hof volgt uit deze bepaling niet dat de conclusies van het Comité voor de douaneautoriteiten een dwingend karakter hebben. De bepaling moet zo worden geïnterpreteerd dat de autoriteiten van de conclusies mogen afwijken 'mits zij hun beslissingen in dit opzicht motiveren'. ${ }^{69}$

Europese administratieve soft law en de nationale rechter

In de Grimaldi-uitspraak, waar het gaat om aanbevelingen die ten opzichte van de lidstaten geen bindende gevolgen beogen, ${ }^{\mathbf{7 0}}$ beklemtoont het Hof dat deze aanbevelingen 'niet kunnen worden geacht geen enkel rechtsgevolg te hebben'. De nationale rechterlijke instanties zijn 'gehouden de aanbevelingen bij de oplossing van de bij hen aanhangige geschillen in aanmerking te nemen, met name wanneer deze duidelijkheid verschaffen over de uitlegging van nationale bepalingen die ter uitvoering ervan zijn vastgesteld of wanneer zij bedoeld zijn om dwingende communautaire bepalingen aan te vullen'.71

Uit de Grimaldi-uitspraak volgt dat de nationale rechter de soft law-handelingen niet zomaar naast zich neer mag leggen. Hij is echter niet gehouden de soft law-handelingen strikt toe te passen of nationale bepalingen conform de soft law-handeling te interpreteren, maar is slechts gehouden de soft law-handelingen 'in aanmerking te nemen'. Administratieve soft law vormt dus een verplicht hulpmiddel voor de rechter bij het vinden van een oplossing voor het geschil. ${ }^{\mathbf{2}}$

Men kan zich afvragen of de overweging van het Hof alleen voor aanbevelingen, of ook voor andere vormen van soft law geldt. In de literatuur wordt in het algemeen aangenomen dat de Grimaldi-uitspraak ook geldt voor administratieve soft law-handelingen met andere benamingen. ${ }^{73}$ Dit lijkt mij juist. Deze lezing sluit aan bij de praktijk van het Hof om handelingen naar hun inhoud te beoordelen, en niet naar het 'jasje' waarin ze zijn gestoken. ${ }^{\mathbf{4}}$ De Grimaldi-uitspraak heeft betrekking op aanbevelingen die ten opzichte van de lidstaten geen bindende gevolgen beogen. Hoe moet de rechter omgaan met soft law-handelingen die (via een onderliggende hard law-bepaling) wel bindende gevolgen beogen voor een lidstaat? Acontrario redenerend kan uit de Grimaldi-uitspraak worden opgemaakt dat een nationale 
rechter verplicht is het nationale overheidshandelen aan deze soft law-handelingen te toetsen en het nationale recht in overeenstemming met de soft law-handeling uit te leggen. ${ }^{75}$ Een 'soft law-conforme uitleg' is echter niet mogelijk als dat betekent dat het nationale recht contra legem moet worden uitgelegd. Dit is immers in strijd met het rechtszekerheidsbeginsel. ${ }^{\mathbf{6}}$ Het lijkt ook niet aannemelijk dat de rechter in zo een situatie de soft law-handeling direct moet toepassen en de nationale bepaling buiten toepassing moet laten, zeker niet als de burger daar de dupe van is. Soft law-handelingen zijn 'tertiair Unierecht' en hebben niet uit zichzelf het vermogen om voorrang te hebben boven het nationale recht. Bovendien zou ook dan het beginsel van rechtszekerheid in gevaar zou komen, omdat soft law-handelingen vaak niet worden gepubliceerd. ${ }^{77}$

\section{Conclusie}

Uit de bespreking van de unierechtelijk eisen die worden gesteld aan de doorwerking van Europese administratieve soft law in de nationale rechtsorde, komt naar voren dat soft lawhandelingen die geen bindende werking genieten op grond van een samenwerkingsplicht of op grond van een secundairrechtelijke rechtsgrondslag, toch op grond van de Grimaldirechtspraak en de comply or explain-praktijk van de Commissie een bindende werking genereren. Op grond van de Grimaldi-rechtspraak is de soft law-handeling voor de rechter een verplicht hulpmiddel bij het vinden van een oplossing voor het geschil. De comply or explainpraktijk van de Commissie zorgt ervoor dat bestuursorganen niet zomaar van een soft lawhandeling kunnen afwijken: ook zij moeten de handeling dus in aanmerking nemen. Deze vormen van bindende werking hebben niet een strikt, maar een gematigd karakter: het bestuur en de rechter moeten met de soft law-handeling rekening houden, maar behoeven deze niet per se strikt te volgen.

\section{Europese administratieve soft law in de Nederlandse rechtspraktijk geïllustreerd: De uitvoering van Europese subsidieregelingen}

In de vorige paragraaf is vanuit unierechtelijk perspectief bezien hoe Europese administratieve soft law in de nationale rechtsorde zou moeten doorwerken. In deze paragraaf wordt de omgang met Europese administratieve soft law in de Nederlandse rechtspraktijk in kaart gebracht en geplaatst in het licht van de hiervoor besproken unierechtelijke eisen. Het onderzoek richt zich op één gebied waarop de nationale autoriteiten met soft law worden geconfronteerd, namelijk op het gebied van de uitvoering van Europese subsidieregelingen.

\subsection{Europese subsidies en Europese administratieve soft law}

Onder een Europese subsidie wordt in dit artikel verstaan een subsidie die (deels) ${ }^{\mathbf{7 8}}$ ten laste komt van de begroting van de Europese Unie. ${ }^{79}$ Europese subsidies worden op grond van subsidieregelingen (meestal verordeningen) verstrekt. ${ }^{\mathbf{8 0}}$ Europese subsidieregelingen kunnen worden uitgevoerd in gecentraliseerd beheer of in gedeeld beheer ${ }^{\mathbf{8 1}} \mathrm{Als}$ een subsidieregeling wordt uitgevoerd in gedeeld beheer vindt een nauwe samenwerking plaats tussen de lidstaat en de Commissie. ${ }^{\mathbf{8 2}}$ Ook als sprake is van 'gecentraliseerd beheer' kan van een (nauwe) samenwerking sprake zijn. Dit is bijvoorbeeld het geval als de Commissie het gecentraliseerde beheer (deels) delegeert aan nationale bestuursorganen. ${ }^{\mathbf{8 3}}$

Bij de uitvoering van Europese subsidieregelingen hebben de lidstaten niet alleen met Europese hard law te maken. Om de uitvoering van de subsidieregelingen soepel(er) en uniform(er) te laten verlopen maakt de Commissie veelvuldig gebruik van soft lawhandelingen. Om deze soft law-handelingen wordt door de lidstaten vaak zelf gevraagd. ${ }^{\mathbf{8 4}}$ Om de doorwerking van Europese administratieve soft law op het terrein van Europese subsidies te kunnen beoordelen in het licht van de Europese eisen is het nodig na te gaan in hoeverre een soft law-handeling bindende werking heeft op grond van een samenwerkingsplicht en aanvaarding of op grond van een secundairrechtelijke rechtsgrondslag. Als sprake is van gedeeld bestuur, van gemengd bestuur, van gedeeld beheer of van gecentraliseerd beheer waarbij vergaande delegatie aan de lidstaten heeft plaatsgevonden, kan er mijns inziens vanuit worden gegaan dat een samenwerkingsplicht 
aanwezig is.

Het heeft overigens alleen zin om stil te staan bij de vraag of van een specifieke samenwerkingsplicht sprake is als de jurisprudentielijn die het Hof heeft uitgezet op het gebied van het staatssteunrecht kan worden doorgetrokken naar het Europese subsidierecht. In de vorige paragraaf is besproken dat voor beantwoording van deze vraag moet worden gekeken naar de aard van het rechtsgebied, bijvoorbeeld naar eventuele verwantschap aan en/of overeenkomsten met het staatssteunrecht.

In het oog springt dat de werelden van staatssteun en subsidies met elkaar verbonden zijn. Het gaat zowel in het geval van staatssteun als in het geval van subsidie om een financiële verstrekking van de overheid aan particulieren. De scheidslijn tussen subsidie en staatssteun is vaak niet scherp.

Een verschil tussen de twee gebieden is echter dat met staatssteun aan de ontvangende ondernemingen een concurrentievoordeel wordt verschaft, terwijl dit concurrentievoordeel ontbreekt als communautaire steun wordt verschaft. ${ }^{\mathbf{8 5}}$ Dit heeft tot gevolg dat onrechtmatig verstrekte staatssteun in beginsel bij de ontvanger moet worden teruggevorderd zodat de situatie wordt hersteld zoals die bestond voor de steunverlening. ${ }^{86}$ Ten aanzien van het terugvorderen van subsidies is het Hof lange tijd minder streng geweest. De ontvanger van een subsidie waarbij zich bij de verstrekking daarvan onregelmatigheden hadden voorgedaan, had meer mogelijkheden om zich tegen terugvordering te verzetten dan de ontvanger van onrechtmatige staatssteun. ${ }^{8} 7$

In de jurisprudentie van het Hof lijkt een tendens zichtbaar waarin een effectieve uitvoering van het Unierecht meer centraal is komen te staan. Het Hof gaat er steeds meer waarde aan hechten dat zich bij de verstrekking van subsidies geen onregelmatigheden voordoen, en als dat wel het geval is, wordt een beroep op het vertrouwens- of rechtszekerheidsbeginsel niet snel gehonoreerd. ${ }^{\mathbf{8 8}}$

Soft law heeft in het licht van deze 'effectiviteitstendens' voor de Commissie een waardevolle functie. Het bevordert een effectieve uitvoering van het Unierecht. Het is te verwachten dat het Hof steeds minder zal accepteren dat bij de uitvoering van Europese subsidieregelingen van soft law-handelingen wordt afgeweken. Het is daarom aannemelijk dat de jurisprudentielijn die het Hof op het terrein van het staatssteunrecht heeft ingezet, kan worden doorgetrokken naar het subsidierecht.

\subsection{Een blik op de Nederlandse rechtspraktijk: De uitvoering van Europese subsidieregelingen en Europese administratieve soft law}

Zoals gezegd breng ik de omgang met Europese administratieve soft law bij de uitvoering van Europese subsidieregelingen in kaart aan de hand van de jurisprudentie van het CBB en de Afdeling bestuursrechtspraak. De meeste Europese subsidiezaken komen terecht bij het CBB. Het gaat dan voornamelijk om zaken over Europese landbouwsubsidies. De Afdeling oordeelt onder meer over zaken waarin verstrekkingen of afwijzingen van subsidies uit het Europees Sociaal Fonds (hierna: ESF) en het Europees Fonds voor Regionale Ontwikkeling (hierna: EFRO) centraal staan.

Hierna bespreek ik eerst de zoekwijze en de verkregen resultaten, vervolgens bespreek ik de relevante uitspraken die zijn gewezen door de Afdeling en door het CBB. In deze bespreking ligt de nadruk op uitspraken van het CBB omdat de zoektocht binnen de CBB-rechtspraak meer relevante uitspraken oplevert.

\subsubsection{Zoekwijze en resultaten}

Op www.rechtspraak.nl is binnen de jurisprudentie van de Afdeling gezocht naar documenten met de volgende benamingen: werkdocument, oriëntatiedocument, interpretatienota, gids, richtsnoeren, mededeling, handboek en handleiding. ${ }^{89}$ Om subsidie-uitspraken heb ik daarnaast de zoekterm 'subsidie' ingevuld. Ook binnen de jurisprudentie van het CBB is naar de genoemde documenten gezocht. Omdat in CBB-uitspraken niet, althans zelden, over 'subsidies' wordt gesproken, heb ik binnen de verkregen resultaten gezocht naar het woord 'steun'. Hieronder is in een tabel per zoekterm het aantal verkregen uitspraken, en daarachter het aantal relevante uitspraken, weergegeven. 
ABRvS

\begin{tabular}{lll}
\multicolumn{1}{c}{ Zoekterm } & \multicolumn{2}{l}{ Resultaat Relevant } \\
Werkdocument + subsidie & o & o \\
Oriëntatiedocument + subsidie & 0 & 0 \\
Interpretatienota + subsidie & 0 & 0 \\
Gids + subsidie & 3 & 0 \\
Richtsnoeren + subsidie & 15 & 4 \\
Mededeling + subsidie + Europese Commissie & 27 & $3^{*}$ \\
Handboek + subsidie & 10 & o \\
Handleiding + subsidie & 30 & o \\
& & \\
* De combinatie mededeling en subsidie levert 154 uitspraken op. Vanwege dit grote aantal heb \\
ik de zoekopdracht verfijnd door de woorden 'Europese Commissie' toe te voegen. De drie \\
gevonden uitspraken worden ook verkregen met de zoektermen 'richtsnoeren' + 'subsidie'.
\end{tabular}

CBB

\section{Zoekterm}

Werkdocument + steun

Oriëntatiedocument + steun

Interpretatienota + steun

Gids + steun

Richtsnoeren + steun

Mededeling + steun + Europese Commissie ${ }^{* * *} 187$

Handboek + steun

Handleiding + steun

\section{Resultaat Relevant}

$193130^{*}$

$3 \quad 3$

$12 \quad 12$

$5 \quad 0$

$110 \quad 45^{* *}$

$11 \quad 0$

* De relevante uitspraken heb ik gevonden door te verfijnen met de zoekterm AGR 49533/2002, het nummer van het werkdocument inzake de kennelijke fout.

**Waarvan 38 kennelijke fout-zaken, 6 interpretatienota-zaken en 1 vijftig bomen-zaak.

*** De combinatie mededeling en subsidie levert 456 uitspraken op. Vanwege dit grote aantal heb ik de zoekopdracht verfijnd door de woorden 'Europese Commissie' toe te voegen.

\subsubsection{Rechtspraak van de Afdeling bestuursrechtspraak}

De zoektocht binnen de jurisprudentie van de Afdeling levert vier relevante uitspraken op. Drie van deze vier uitspraken worden zowel verkregen met het zoeken naar de term 'mededeling' als met het zoeken naar de term 'richtsnoeren'.

In één van de vier uitspraken wordt een beroep gedaan op een mededeling van de Commissie, maar komt de Afdeling aan een inhoudelijke beoordeling niet toe. ${ }^{\mathbf{9 0}}$ De overige drie zaken, die erg op elkaar lijken, bespreek ik hierna kort. ${ }^{\mathbf{1 1}}$ Deze drie zaken zijn ook de (enige) relevante uitspraken die het resultaat zijn van het zoeken met de term 'mededeling'.

Het gaat in de drie uitspraken om een subsidie verstrekt uit het Europees Sociaal Fonds. De Europese administratieve soft law-handeling in deze zaken is de Mededeling van de Commissie tot vaststelling van de richtsnoeren voor de operationele programma's/globale subsidies die de lidstaten worden verzocht op te stellen in het kader van een communautair initiatief in zake 'Werkgelegenheid en ontwikkeling van menselijke hulpbronnen'.92 In Nederland is de Regeling Communautair Initiatief Werkgelegenheid-II opgesteld, waarin de richtsnoeren zijn neergelegd.

De rechter onderzoekt niet in hoeverre de richtsnoeren voor Nederland bindende werking hebben. Dit verbaast niet, omdat de Nederlandse wettelijke regeling reeds juridisch verbindend is. Toch is het van belang of sprake is van bindende werking van de richtsnoeren, bijvoorbeeld voor de vraag in hoeverre de richtsnoeren moeten worden gevolgd bij de uitlegging van de 
wettelijke regeling. Het Europees Sociaal Fonds is een structuurfonds waarvan de uitvoering plaatsvindt in gemengd bestuur. Het bestaan van een samenwerkingsplicht kan daarom worden aangenomen. De richtsnoeren zijn aanvaard doordat zij in een wettelijke regeling zijn neergelegd. De richtsnoeren hebben voor Nederland dus bindende werking op grond van het bestaan van een samenwerkingsplicht en aanvaarding.

Deze uitspraken laten zien dat de praktijk van de wetgever bepalend kan zijn voor de doorwerking van Europese soft law-handelingen. Door de soft law-handeling in een nationale wettelijke regeling neer te leggen, bestaat voor het bestuur geen mogelijkheid meer tot afwijking. Vanuit unierechtelijk perspectief bezien, is dit een goede zaak. De Commissie ziet immers het liefst dat een soft law-handeling door de autoriteiten van de lidstaten wordt gevolgd.93

Tot slot merk ik nog op dat het zo kan zijn dat soft law-handelingen in documenten zijn neergelegd die een andere benaming hebben dan de documentnamen waarnaar is gezocht. Een uitgebreider onderzoek, waarin alle subsidiezaken afzonderlijk worden geanalyseerd, zou deze uitspraken (als ze er zijn) boven water kunnen krijgen.

\subsubsection{Rechtspraak van het College van Beroep voor het Bedrijfsleven}

De zoektocht binnen de rechtspraak van het CBB leidt tot meer resultaat. De zoektermen werkdocument, interpretatienota, oriëntatiedocument en richtsnoeren leveren relevante uitspraken op. De resultaten verkregen met de zoekterm 'richtsnoer' behandel ik niet als aparte categorie, omdat deze uitspraken ook deel uit maken van de gevonden uitspraken met de andere zoektermen. De verklaring hiervoor is dat de term richtsnoer wordt gebruikt om de inhoud van een interpretatienota, een werkdocument of een oriëntatiedocument te beschrijven. In het overgrote deel van de uitspraken verkregen met de zoekterm 'werkdocument' staat het Werkdocument AGR 49533/2002 inzake de uitleg van het begrip 'kennelijke fout' centraal.94 Deze zaken noem ik hierna de 'kennelijke fout-zaken'.

In elf van de twaalf gevonden uitspraken waarin de term interpretatienota voorkomt, gaat het om interpretatienota's die gelieerd zijn aan Verordening 2342/199o betreffende een minimumpercentage voor het gebruik van premierechten voor zoogkoeien. Deze zaken noem ik hier de 'interpretatienota-zaken'.

In drie CBB-uitspraken komt de term oriëntatiedocument voor. Het gaat om het Oriëntatiedocument AGRI/60363/2005-REVI van de Europese Commissie waarin richtsnoeren zijn neergelegd voor de controle ter plaatse en de meting van de oppervlakte van landbouwgrond 95 Omdat in deze uitspraken het in het Oriëntatiedocument neergelegde 'vijftig bomen-criterium' centraal staat, noem ik deze zaken de 'vijftig bomen-zaken'.

In alle gevonden zaken gaat het om landbouwsubsidies. Voorheen vloeiden de landbouwsubsidies voort uit het EOGFL: het Europees Oriëntatie- en Garantiefonds voor de landbouw. ${ }^{\mathbf{9 6}}$ Dit fonds omvatte de afdeling Garantie en de afdeling Oriëntatie. De afdeling Oriëntatie (EOGFL - O) was een structuurfonds. ${ }^{97}$ De afdeling Garantie was officieel geen structuurfonds omdat dit fonds in de eerste plaats een gemeenschappelijke ordening van de landbouwmarkten tot doel had..$^{\mathbf{9 8}}$ In het jaar 2005 heeft het EOGFL plaatsgemaakt voor twee 'gewone fondsen': het Europees Landbouw Garantiefonds (ELGF) en het Europees Landbouwfonds voor Plattelandsontwikkeling (ELFPO).99

Hierna analyseer ik aan de hand van de gevonden jurisprudentie hoe de Nederlandse wetgever, bestuursorganen en rechter met de drie genoemde soft law-documenten omgaan en bespreek ik deze praktijk in het licht van de unierechtelijke eisen.

\subsubsection{De kennelijke fout-zaken}

Omwille van de omvang en de leesbaarheid van dit artikel bespreek ik niet alle 'kennelijke foutzaken' afzonderlijk. Omdat de zaken zeer op elkaar lijken worden hierna twee kennelijke foutzaken uitgelicht, namelijk de uitspraak van het CBB van 29 maart 2006 (deze zaak representeert de 'vroege' kennelijke fout-zaken 1) ${ }^{\mathbf{1 0 0}}$ en de uitspraak van het CBB van 25 januari 2010 (deze zaak representeert de 'late' kennelijke fout-zaken). ${ }^{\mathbf{1 0 1}}$

Een vroege kennelijke fout-zaak: casus en context 
Het bestreden besluit in deze zaak betreft de beslissing van de Minister van Landbouw, Natuur en Voedselkwaliteit om de aanvraag van appellante voor akkerbouwsteun op grond van de Regeling EG-steunverlening akkerbouwgewassen af te wijzen. Deze uitspraak valt nog onder het regime van het EOGFL. Uit de uitspraak blijkt namelijk dat de Verordening 3508/92, die voorziet in de invoering van een geïntegreerd beheers- en controlesysteem, van toepassing is. 102 Deze Verordening is aangenomen met het oog op een goede uitvoering van het EOGFL. Omdat de Verordening inzake akkerbouwgewassen uit 1992 tot doel heeft om te komen tot een beter marktevenwicht, ${ }^{\mathbf{1 0 3}}$ lijkt het te gaan om steun uit de Afdeling Garantie. ${ }^{\mathbf{1 0 4}}$ Ter uitvoering van Verordening 3508/93 heeft de Commissie Verordening 2419/2001 aangenomen. ${ }^{105}$ Onder verwijzing naar artikel 32 van laatstgenoemde Verordening wijst de minister de aanvraag van appellante af, omdat in de aanvraag een verschil bestaat tussen de aangevraagde oppervlakte maïs en de geconstateerde oppervlakte maïs.

In dit geschil staat de vraag centraal of vanwege dit grote verschil tussen de aangevraagde en geconstateerde oppervlakte sprake is van een 'kennelijke fout' in de aanvraag. Artikel 12 van Verordening 2419/2001 bepaalt dat in geval van een kennelijke fout de steunaanvraag te allen tijde na de indiening kan worden aangepast. Volgens appellant is sprake van een kennelijke fout en had verweerder derhalve gelegenheid tot verbetering moeten geven, en is de afwijzing daarom onterecht. De minister betoogt dat geen sprake is van een kennelijke fout, en voert daartoe aan dat niet uit de aanvraag zelf zou blijken dat de gedane opgave onjuist is. ${ }^{\mathbf{0 6}}$ Hij laat zich in dit oordeel leiden door het Werkdocument AGR 495533/2002 dat richtsnoeren geeft voor de uitleg van artikel 12. ${ }^{\mathbf{1 0}}$ Dit Werkdocument is niet gepubliceerd in het Publicatieblad van de Europese Unie, maar is wel te vinden op het internet. ${ }^{\mathbf{1 0 8}}$ Het document is niet in Nederlandse wet- of regelgeving neergelegd.

Volgens het College is het werkdocument niet aan te merken als een verordening, een richtlijn of een beschikking in de zin van artikel 249 EG. Daarom komt aan het Werkdocument volgens het CBB geen verbindende kracht toe. Dit Werkdocument bevat 'bovendien niet een limitatief systeem van mogelijke gronden om wijziging van de aanvraag na de sluitingsdatum op grond van een kennelijke fout toe te laten', aldus het CBB. Het voorgaande neemt volgens het CBB niet weg dat verweerder de bevoegdheid om aan de hand van het document, binnen de door Verordening (EG) nr. 2419/2001 getrokken grenzen, een vaste beleidslijn te ontwikkelen, zeker niet ontzegd kan worden'.

\section{Een late kennelijke fout-zaak: casus en context}

In de tweede te bespreken kennelijke fout-zaak, die illustrerend is voor de 'latere' kennelijke fout-zaken, staat - niet verrassend - de vraag centraal of sprake is van een kennelijke fout, nu in de zin van artikel 19 van Verordening nr. 796/2004. ${ }^{\mathbf{1 0 9}}$ Uit de toepasselijkheid van deze verordening blijkt dat ook deze zaak nog valt onder het regime van het EOGFL.

Omdat de casus wordt ingekleurd door andere feiten, maar de rechtsvraag dezelfde is als in de 'vroege' kennelijke fout-zaak, volsta ik met een beknopte bespreking van een aantal overwegingen van het CBB. De bestuurlijke praktijk is niet anders dan in de hiervoor besproken zaak: de Minister van LNV hanteert het Werkdocument als richtsnoer. Ook de wetgever is nog steeds niet in actie gekomen. De inhoud van het Werkdocument is (nog) niet in Nederlandse wetgeving terug te vinden.

Het is vooral de praktijk van de rechter die in deze zaak opvalt. De rechter verwijst terug naar eerdere jurisprudentie in kennelijke fout-zaken. Het CBB overweegt: 'Het College heeft het Werkdocument in eerdere jurisprudentie aldus uitgelegd en samengevat, dat van een kennelijke fout over het algemeen alleen kan worden gesproken indien verweerder bij een summier onderzoek na ontvangst van de aanvraag had kunnen vaststellen dat de aanvraag waarschijnlijk geen goede weergave was van hetgeen de aanvrager beoogde aan te vragen'. Het CBB merkt verder op dat het 'voor de Europese Commissie, blijkens het document, voorts van groot belang is dat vastgesteld wordt dat een fout onopzettelijk gemaakt is, dat de landbouwer te goeder trouw gehandeld heeft en dat ieder gevaar van bedrog wordt uitgesloten'. Deze laatste overweging lijkt een aanvulling te zijn op de eerdere kennelijke fout jurisprudentie.

De kennelijke fout-zaken: beoordeling vanuit unierechtelijk perspectief 
De vraag is hoe in het licht van de unierechtelijke eisen tegen de hiervoor geschetste praktijken van de rechter, het bestuur en de wetgever moet worden aangekeken.

Opvallend is dat de Minister het Werkdocument als leidraad hanteert bij de vraag of sprake is van een kennelijke fout. Het is echter de vraag of hij hiertoe ook gehouden was. Het gaat om een Werkdocument dat gelieerd is aan uitvoeringsverordeningen die voorzien in een geïntegreerd beheers- en controlesysteem in het kader van het EOGFL-G, dat voorziet in een nauwe samenwerking tussen de lidstaten en de Commissie. Op grond van deze nauwe samenwerking kan worden aangenomen dat sprake is van gemengd bestuur, en derhalve ook van een samenwerkingsplicht. Maar is het Werkdocument door Nederland aanvaard? De uitspraak geeft hierover geen aanwijzingen. Het zou natuurlijk zo kunnen zijn dat de minister nauw betrokken is geweest bij de voorbereiding van het Werkdocument, en het document toen heeft goedgekeurd. Het kan echter ook zo zijn dat de minister het Werkdocument (expliciet) niet heeft aanvaard, wat betekent dat het document geen bindende werking heeft.

Door het Werkdocument te volgen, vaart de Minister een gemakkelijke en veilige koers. ${ }^{\mathbf{1 1 0}} \mathrm{Hij}$ vaart een gemakkelijke koers omdat de Commissie in de praktijk het comply or explainprinciple toepast. De Minister zou een afwijking moeten verantwoorden. De Minister vaart een veilige koers omdat hij niet het risico loopt de subsidie per slot van rekening uit eigen zak te moeten betalen. Dit risico zou de Minister wel lopen als hij een gedragslijn zou hebben ontwikkeld die van het Werkdocument afwijkt en op basis daarvan tot de conclusie zou zijn gekomen dat wél sprake was van een kennelijke fout. Als het vervolgens in de ogen van de Commissie niet gaat om een kennelijke fout, zou de nationale staatskas moeten worden aangesproken.

De rechter neemt in de als eerst besproken zaak als uitgangspunt dat het document niet verbindend is. Het College schenkt echter geen aandacht aan de jurisprudentie van het Hof waarin is bepaald dat soft law-handelingen onder omstandigheden een bindende werking kunnen hebben. Vanuit unierechtelijk perspectief bezien had het CBB op zijn minst moeten nagaan of van (enige mate van) bindende werking sprake is. Het is mij overigens niet duidelijk waarom het $\mathrm{CBB}$ ter onderbouwing van zijn conclusie verwijst naar de in het document gebezigde bewoordingen. Uit de jurisprudentie van het Hof blijkt immers niet dat het van de gebezigde bewoordingen afhangt of een soft law-handeling bindende werking toekomt; daarvoor is een grondslag of samenwerkingsplicht in Europese hard law nodig. Als eenmaal is vastgesteld dat een soft law-handeling bindende werking heeft, kunnen de bewoordingen wel van invloed zijn op de mate van bindende werking. ${ }^{\mathbf{1 1 1}}$

In de tweede kennelijke fout-zaak gaat de rechter uitgebreider in op de inhoud en de uitlegging van het document. Opvallend is vooral dat het CBB veel waarde hecht aan de intentie van de Europese Commissie die in het Werkdocument doorschemert. De rechter lijkt daarmee te willen inspelen op de bestuurlijke praktijk om zoveel mogelijk in de pas te lopen met de Europese Commissie. De Commissie juicht dit waarschijnlijk toe. Niet alleen het bestuur maar ook de nationale rechter danst naar haar pijpen.

Tot slot is het opvallend dat het Werkdocument door de Nederlandse wetgever niet in wetgeving is neergelegd. Over dit stilzitten van de wetgever zal op Europees niveau niet worden geklaagd. In het algemeen bestaat er immers geen verplichting voor de wetgever om stoft lawhandelingen in wetgeving neer te leggen. Uit de uitspraak blijkt bovendien niet dat in dit specifieke geval voor de wetgever een verplichting bestond om actie te ondernemen (bijvoorbeeld om een regeling op te stellen die in overeenstemming zou moeten zijn met het Werkdocument).

\subsubsection{De vijftig bomen-zaken}

De eerste van de drie vijftig bomen-zaken is gewezen op 27 oktober $2010 .{ }^{\mathbf{1 1 2}}$ In de latere twee zaken wordt naar deze eerste uitspraak verwezen. ${ }^{\mathbf{1 1 3}}$ Hierna bespreek ik daarom alleen de eerste vijftig bomen-zaak.

Een vijftig bomen-zaak: casus en context

Uit artikel 44 lid 1 en 2 van Verordening 1782/2003 volgt dat onder een subsidiabele hectare wordt verstaan alle 'landbouwgrond' van het bedrijf in de vorm van bouwland en blijvend 
grasland. Artikel 8 van Verordening 796/2004 bepaalt kort gezegd dat ook een perceel met bomen als een perceel landbouwgrond kan worden beschouwd als op dat perceel landbouwactiviteiten kunnen worden verricht. Deze verordeningen vormen het rechtskader in deze zaak, wat betekent dat (wederom) het regime van het EOGFL van toepassing is. Dit rechtskader wordt verder ingevuld door het oriëntatiedocument AGRI/60363/2005-REV1. Artikel 8 van dit document bepaalt: 'overeenkomstig artikel 8 lid 1 van Verordening $\mathrm{nr}$. 796/2004 moeten met bomen beplante oppervlakten (...) binnen een perceel landbouwgrond, met een plantdichtheid van meer dan 50 bomen per hectare, worden beschouwd als oppervlakten die niet voor steun in aanmerking komen. Uitzonderingen kunnen eventueel worden gemaakt voor gemengde teelten (...) en om ecologische en milieutechnische redenen. Mogelijke uitzonderingen moeten op voorhand door de lidstaten worden vastgesteld.' Het Oriëntatiedocument is niet door de Commissie gepubliceerd en op het moment van de uitspraak niet in Nederlandse wet- of regelgeving neergelegd.

De Minister wijst, onder verwijzing naar het Oriëntatiedocument, een aanvraag voor bedrijfstoeslag voor een hectare af omdat op de percelen meer dan vijftig bomen per hectare staan. Hij geeft aan het Oriëntatiedocument te hanteren als dwingend voorschrift. Daarbij neemt de Minister in aanmerking dat Nederland geen uitzonderingen heeft vastgesteld op het 50 bomen-criterium. In de procedure staat de vraag centraal of de Minister terecht en op goede gronden de aanvraag heeft afgewezen.

Het College overweegt dat de Minister het karakter van het Oriëntatiedocument miskent door het niet als richtsnoer te hanteren maar als dwingend voorschrift. De omstandigheid dat Nederland geen uitzonderingen heeft vastgesteld, brengt volgens het College niet mee dat het verweerder niet vrij zou staan om tot een individuele beoordeling van de steunwaardigheid van de percelen van appellante over te gaan. Voor een individuele beoordeling bestaat in ieder geval aanleiding als door de landbouwer bijzondere omstandigheden naar voren zijn gebracht, zoals in dit geval de stelling dat de meeste bomen langs de kavelsloten of afrastering staan zodat landbouwmachines zonder problemen hun werk kunnen doen. Het besluit tot afwijzing van de aanvraag is volgens het College ondeugdelijk gemotiveerd.

\section{De vijftig bomen-zaken: beoordeling vanuit unierechtelijk perspectief}

Ook in deze zaak wordt de soft law-handeling door de Minister gevolgd. De Minister hanteert het Oriëntatiedocument zelfs als dwingend voorschrift. De reden hiervoor kan net als in de besproken kennelijke fout-zaak met name worden gevonden in de afhankelijkheid van de lidstaat van de Commissie als het gaat om unierechtelijke steun. Als de Minister handelt in lijn met het soft law-document loopt hij het minste risico de steun uit eigen zak te moeten betalen. Doordat het CBB voor deze opstelling van het bestuur een stokje steekt, loopt de Minister nu alsnog het risico voor de steun te moeten opdraaien. Immers, de kans bestaat dat de Commissie met de afwijking van het vijftig bomen-criterium niet akkoord gaat, zeker nu de afwijking niet in een van te voren vastgestelde uitzondering is neergelegd.

Interessant is verder dat het CBB het Werkdocument bestempeld als een 'aanbeveling van de Commissie waaraan niet de status van een wettelijke voorschrift kan worden toegekend'. Net als in de kennelijke fout-zaken gaat het CBB voorbij aan de jurisprudentie van het Hof betreffende bindende werking van administratieve soft law-handelingen. Een samenwerkingsplicht lijkt wel aanwezig, omdat de uitvoeringsverordening van het EOGFL waaraan het Werkdocument gelieerd is, voorziet in een geïntegreerd beheers- en controlesysteem dat stoelt op een nauwe samenwerking tussen de lidstaten en de Commissie. Uit de uitspraak blijkt echter niet dat het Oriëntatiedocument (expliciet) door Nederland is aanvaard.

Als de uitspraak op dit moment zou zijn gewezen, zou dit anders zijn. Het vijftig bomencriterium is inmiddels aanvaard doordat deze is neergelegd in de Regeling GLB-inkomenssteun 2006. ${ }^{114}$ Dit betekent dat als deze zaak nu had gespeeld het vijftig bomen-criterium een bindende werking zou hebben. Deze bindende werking van het Oriëntatiedocument speelt echter in de praktijk niet in de eerste plaats een rol, omdat de Regeling waarin het criterium is neergelegd reeds juridisch verbindend is. Door de Commissie zal het overigens worden toegejuicht dat het criterium in nationale regelgeving is neergelegd. 


\subsubsection{De interpretatienota-zaken}

Zoals gezegd staan in elf van de twaalf gevonden zaken de Interpretatienota's 51 en 26 van de Europese Commissie centraal. ${ }^{\mathbf{1 1 5}}$ In de twaalfde zaak $^{\mathbf{1 1 6}}$ gaat het om een interpretatienota die een nadere precisering geeft van het begrip 'zoogkoe' zoals gehanteerd in artikel 3 lid 1 onder $\mathrm{f}$ van Verordening 1254/1999. ${ }^{117}$ Deze zaak laat geen andere handelwijze van het bestuur, de rechter of de wetgever zien dan de andere Interpretatienota-zaken. Daarom bespreek ik deze zaak niet afzonderlijk. Ik volsta met een bespreking van één van de elf zaken waarin de interpretatienota's 26 en 51 centraal staan, namelijk de uitspraak van het CBB van 30 november 2006. ${ }^{\mathbf{1 1 8}}$ Deze uitspraak vormt de 'standaarduitspraak' waarnaar in acht van de andere uitspraken wordt verwezen. ${ }^{\mathbf{1 1 9}}$

\section{Een interpretatienota-zaak: casus en context}

Artikel 6 van Verordening 1254/1999 van de Raad houdende een gemeenschappelijke ordening der markten in de sector rundvlees, bepaalt dat aan producenten die zoogkoeien houden, op hun verzoek een premie voor het aanhouden van zoogkoeien kan worden verleend. ${ }^{\mathbf{1 2 0}}$ Het gaat in deze zaak om premies die worden gefinancierd uit het Europees Oriëntatie- en Garantiefonds voor de Landbouw - Afdeling Garantie. ${ }^{\mathbf{1 2 1}}$

In artikel 23 lid 4 van de Uitvoeringsverordening 2342/1999 van de Commissie is een minimumpercentage voor het gebruik van premierechten neergelegd. ${ }^{\mathbf{1 2 2}}$ Het tweede lid van artikel 23 bepaalt dat als een producent niet tenminste van het minimumpercentage van zijn rechten gebruik maakt, het niet gebruikte deel aan de nationale reserve wordt overgedragen, behalve (onder meer) in uitzonderlijke, naar behoren gemotiveerde gevallen. In de Interpretatienota's 26 en 51 worden voorbeeldsituaties geschetst waarin sprake is van een uitzonderlijk, naar behoren gemotiveerd geval. De Interpretatienota's zijn niet gepubliceerd. ${ }^{\mathbf{1 2 3}}$ Eén van de rechtsvragen in het geschil is of van een uitzonderlijk, naar behoren gemotiveerd geval sprake is. Verweerder laat zich bij de beantwoording van deze vraag hoofdzakelijk leiden door de Interpretatienota's 26 en 51 . Hij stelt zich op het standpunt dat van een uitzonderlijk, naar behoren gemotiveerd geval geen sprake is.

Volgens het College behelzen de Interpretatienota's 'naar hun aard' geen bindende regels. Zij hebben alleen betrekking op enkele voorgelegde voorbeeldsituaties. Het College acht het daarom aanvaardbaar dat de interpretatienota's als richtsnoer worden gehanteerd. Verweerder heeft echter 'een eigen verantwoordelijkheid om aan de hand van de feiten en de omstandigheden van het geval te beoordelen of sprake is van een 'uitzonderlijk, naar behoren gemotiveerd geval".

Het College concludeert dat een deel van de niet-gebruikte premierechten ten onrechte aan de nationale reserve is toegevoegd. Het College komt tot deze conclusie door zich te baseren op het eerste en derde in Interpretatienota nr. 51 genoemde voorbeeld. Verweerder had moeten vaststellen dat sprake is van een uitzonderlijk, naar behoren gemotiveerd geval als bedoeld in artikel 23 tweede lid van Verordening 2343/1999, aldus het College.

\section{De interpretatienota-zaken: beoordeling vanuit unierechtelijk perspectief}

In het oog springt dat het bestuur, net als het geval was in de hiervoor geanalyseerde zaken, de Interpretatienota's van de Commissie strikt volgt. Er kan mijns inziens echter van worden uitgegaan dat de Interpretatienota's geen bindende werking hebben. Weliswaar zou van een samenwerkingsverplichting kunnen worden gesproken (de zoogdierpremie vloeit immers voort uit een nauw samenwerkingsverband in het kader van 'gemengd' bestuur, het EOGFL-G) maar het lijkt niet dat de Interpretatienota's expliciet door de Nederlandse regering zijn aanvaard. De interpretatienota's vormen namelijk een reactie van de Commissie op verschillende vanuit Spanje en het Verenigd Koninkrijk (dus niet vanuit Nederland) voorgelegde hypothetische gevallen. ${ }^{124}$

Het CBB acht het niet aanvaardbaar dat het bestuur de Interpretatienota's strikt volgt. Het verlangt dat de Minister een individuele beoordeling maakt. Dit lijkt in overeenstemming met het doel van de Interpretatienota's te zijn waarin slechts voorbeelden worden genoemd van situaties waarin sprake is van een uitzonderlijk, naar behoren gemotiveerd geval. De rechter 
had echter, zoals ook in de andere zaken het geval is, beter moeten motiveren waarom de Interpretatienota's geen bindende werking hebben.

In de uitspraak komt verder naar voren dat het volgen van de Interpretatienota's voor het bestuur een zelfbindende werking heeft. Het CBB komt namelijk aan de hand van de Interpretatienota's tot de conclusie dat de Minister tot een verkeerde beslissing is gekomen. De Minister werkt zich in de nesten door de nota's te volgen, maar deze in de ogen van het CBB niet op de juiste manier uit te leggen. Een deel van de premierechten is daardoor onterecht aan de staatskas toegevoegd.

Overigens had het CBB de Interpretatienota's ook in aanmerking moet nemen in het geval de Minister de Nota's niet als leidraad zou hebben gehanteerd. Volgens de Grimaldi-uitspraak zijn de soft law-handelingen voor het CBB een verplicht hulpmiddel zijn ter interpretatie van Europese hard law-regels. ${ }^{\mathbf{1 2 5}}$ Het CCB lijkt echter de Interpretatienota's bij zijn beslissing in aanmerking te nemen omdat de Minister heeft aangegeven de Interpretatienota's te volgen. ${ }^{\mathbf{1 2 6}}$

\subsection{Conclusie}

In kaart is gebracht hoe het bestuur, de wetgever en de rechter blijkens de jurisprudentie in Nederland omgaan met vier soft law-handelingen die gelieerd zijn aan Europese subsidieregelingen. Uit deze afzonderlijke besprekingen is een aantal grote lijnen te trekken. Opvallend is in de eerste plaats dat het bestuur de soft law-handelingen als leidraad hanteert. De voornaamste reden hiervoor lijkt te zijn dat het voor de lidstaten van belang is om zoveel mogelijk met de Commissie in de pas te lopen omdat de lidstaten de verstrekte subsidies bij de Commissie moeten declareren. Dit betekent dat de soft law-handelingen de facto een bindende werking genereren, die voortvloeit uit een (financiële) afhankelijkheid van de lidstaat ten opzichte van de Commissie. In het oog moet worden gehouden dat deze de facto bindende werking op andere terreinen dan het subsidierecht, waar een directe (financiële) afhankelijkheidsrelatie niet bestaat of minder evident is, waarschijnlijk minder sterk is. Overigens zal ook op deze terreinen in ieder geval in enige mate sprake zijn van een de facto bindende werking vanwege de comply or explain-praktijk van de Commissie. Ook is op deze terreinen in ieder geval sprake van een gematigd juridisch bindende werking via de Grimaldirechtspraak van het Hof. ${ }^{\mathbf{1 2 7}}$

De uitspraken van de rechter laten net als de bestuurlijke praktijk een eenduidig beeld zien. De rechter gaat er steeds vanuit dat soft law-handelingen geen bindende werking kunnen hebben. De redenering is simpel: soft law-handelingen zijn geen verordeningen, richtlijnen of andere vorm van hard law. De rechter heeft geen oog voor de rechtspraak van het Hof waaruit blijkt dat soft law-handelingen wel degelijk een bindende werking kunnen generen.

Als het bestuur eenmaal aangeeft de soft law-handeling als uitgangspunt te nemen, neemt de rechter de soft law-handeling in aanmerking in zijn beoordeling. Het College gaat zelfs op zoek naar de intentie van de Commissie. Vanuit unierechtelijk perspectief bezien is dit gebruik van soft law als interpretatiemaatstaf toe te juichen. Volgens het Hof zou de rechter zelfs een stap verder moeten gaan door de soft law-handeling, ook als deze niet door het bestuursorgaan als richtsnoer wordt gehanteerd, als hulpmiddel bij het vinden van een oplossing voor het aanhangige geschil te gebruiken. ${ }^{\mathbf{1 2 8}}$

Tot slot is de praktijk van de wetgever in kaart gebracht. Twee van de vier soft law-handelingen zijn (inmiddels) neergelegd in wetgeving. Het lijkt voor de wetgever dus geen gewoonte om soft law-handelingen in wetgeving neer te leggen. De Europese Commissie heeft op deze praktijk (waarschijnlijk) niet veel aan te merken. In principe is de wetgever immers niet verplicht om Europese administratieve soft law in wetgeving neer te leggen. ${ }^{\mathbf{2 9}}$

In het voorgaande is de doorwerking van administratieve soft law in de Europese subsidiepraktijk onderzocht.

Een vroege kennelijke fout-zaak: casus en context

Het bestreden besluit in deze zaak betreft de beslissing van de Minister van Landbouw, Natuur en Voedselkwaliteit om de aanvraag van appellante voor akkerbouwsteun op grond van de Regeling EG-steunverlening akkerbouwgewassen af te wijzen. Deze uitspraak valt nog onder het regime van het EOGFL. Uit de uitspraak blijkt namelijk dat de Verordening 3508/92, die 
voorziet in de invoering van een geïntegreerd beheers- en controlesysteem, van toepassing is. 130 Deze Verordening is aangenomen met het oog op een goede uitvoering van het EOGFL. Omdat de Verordening inzake akkerbouwgewassen uit 1992 tot doel heeft om te komen tot een beter marktevenwicht, ${ }^{\mathbf{1 3 1}}$ lijkt het te gaan om steun uit de Afdeling Garantie. ${ }^{\mathbf{1 3 2}}$ Ter uitvoering van Verordening 3508/93 heeft de Commissie Verordening 2419/2001 aangenomen. ${ }^{\mathbf{1 3 3}}$ Onder verwijzing naar artikel 32 van laatstgenoemde Verordening wijst de minister de aanvraag van appellante af, omdat in de aanvraag een verschil bestaat tussen de aangevraagde oppervlakte maïs en de geconstateerde oppervlakte maïs.

In dit geschil staat de vraag centraal of vanwege dit grote verschil tussen de aangevraagde en geconstateerde oppervlakte sprake is van een 'kennelijke fout' in de aanvraag. Artikel 12 van Verordening 2419/2001 bepaalt dat in geval van een kennelijke fout de steunaanvraag te allen tijde na de indiening kan worden aangepast. Volgens appellant is sprake van een kennelijke fout en had verweerder derhalve gelegenheid tot verbetering moeten geven, en is de afwijzing daarom onterecht. De minister betoogt dat geen sprake is van een kennelijke fout, en voert daartoe aan dat niet uit de aanvraag zelf zou blijken dat de gedane opgave onjuist is. ${ }^{\mathbf{1 3 4}} \mathrm{Hij}$ laat zich in dit oordeel leiden door het Werkdocument AGR 495533/2002 dat richtsnoeren geeft voor de uitleg van artikel 12. ${ }^{\mathbf{1 3 5}}$ Dit Werkdocument is niet gepubliceerd in het Publicatieblad van de Europese Unie, maar is wel te vinden op het internet. ${ }^{\mathbf{1 3 6}}$ Het document is niet in Nederlandse wet- of regelgeving neergelegd.

Volgens het College is het werkdocument niet aan te merken als een verordening, een richtlijn of een beschikking in de zin van artikel 249 EG. Daarom komt aan het Werkdocument volgens het CBB geen verbindende kracht toe. Dit Werkdocument bevat 'bovendien niet een limitatief systeem van mogelijke gronden om wijziging van de aanvraag na de sluitingsdatum op grond van een kennelijke fout toe te laten', aldus het CBB. Het voorgaande neemt volgens het CBB niet weg dat verweerder de bevoegdheid om aan de hand van het document, binnen de door Verordening (EG) nr. 2419/2001 getrokken grenzen, een vaste beleidslijn te ontwikkelen, zeker niet ontzegd kan worden'.

Een late kennelijke fout-zaak: casus en context

In de tweede te bespreken kennelijke fout-zaak, die illustrerend is voor de 'latere' kennelijke fout-zaken, staat - niet verrassend - de vraag centraal of sprake is van een kennelijke fout, nu in de zin van artikel 19 van Verordening nr. 796/2004. ${ }^{137}$ Uit de toepasselijkheid van deze verordening blijkt dat ook deze zaak nog valt onder het regime van het EOGFL.

Omdat de casus wordt ingekleurd door andere feiten, maar de rechtsvraag dezelfde is als in de 'vroege' kennelijke fout-zaak, volsta ik met een beknopte bespreking van een aantal overwegingen van het CBB. De bestuurlijke praktijk is niet anders dan in de hiervoor besproken zaak: de Minister van LNV hanteert het Werkdocument als richtsnoer. Ook de wetgever is nog steeds niet in actie gekomen. De inhoud van het Werkdocument is (nog) niet in Nederlandse wetgeving terug te vinden.

Het is vooral de praktijk van de rechter die in deze zaak opvalt. De rechter verwijst terug naar eerdere jurisprudentie in kennelijke fout-zaken. Het CBB overweegt: 'Het College heeft het Werkdocument in eerdere jurisprudentie aldus uitgelegd en samengevat, dat van een kennelijke fout over het algemeen alleen kan worden gesproken indien verweerder bij een summier onderzoek na ontvangst van de aanvraag had kunnen vaststellen dat de aanvraag waarschijnlijk geen goede weergave was van hetgeen de aanvrager beoogde aan te vragen'. Het CBB merkt verder op dat het 'voor de Europese Commissie, blijkens het document, voorts van groot belang is dat vastgesteld wordt dat een fout onopzettelijk gemaakt is, dat de landbouwer te goeder trouw gehandeld heeft en dat ieder gevaar van bedrog wordt uitgesloten'. Deze laatste overweging lijkt een aanvulling te zijn op de eerdere kennelijke fout jurisprudentie.

De kennelijke fout-zaken: beoordeling vanuit unierechtelijk perspectief

De vraag is hoe in het licht van de unierechtelijke eisen tegen de hiervoor geschetste praktijken van de rechter, het bestuur en de wetgever moet worden aangekeken.

Opvallend is dat de Minister het Werkdocument als leidraad hanteert bij de vraag of sprake is van een kennelijke fout. Het is echter de vraag of hij hiertoe ook gehouden was. Het gaat om 
een Werkdocument dat gelieerd is aan uitvoeringsverordeningen die voorzien in een geïntegreerd beheers- en controlesysteem in het kader van het EOGFL-G, dat voorziet in een nauwe samenwerking tussen de lidstaten en de Commissie. Op grond van deze nauwe samenwerking kan worden aangenomen dat sprake is van gemengd bestuur, en derhalve ook van een samenwerkingsplicht. Maar is het Werkdocument door Nederland aanvaard? De uitspraak geeft hierover geen aanwijzingen. Het zou natuurlijk zo kunnen zijn dat de minister nauw betrokken is geweest bij de voorbereiding van het Werkdocument, en het document toen heeft goedgekeurd. Het kan echter ook zo zijn dat de minister het Werkdocument (expliciet) niet heeft aanvaard, wat betekent dat het document geen bindende werking heeft.

Door het Werkdocument te volgen, vaart de Minister een gemakkelijke en veilige koers. ${ }^{\mathbf{1 3 8}} \mathrm{Hij}$ vaart een gemakkelijke koers omdat de Commissie in de praktijk het comply or explainprinciple toepast. De Minister zou een afwijking moeten verantwoorden. De Minister vaart een veilige koers omdat hij niet het risico loopt de subsidie per slot van rekening uit eigen zak te moeten betalen. Dit risico zou de Minister wel lopen als hij een gedragslijn zou hebben ontwikkeld die van het Werkdocument afwijkt en op basis daarvan tot de conclusie zou zijn gekomen dat wél sprake was van een kennelijke fout. Als het vervolgens in de ogen van de Commissie niet gaat om een kennelijke fout, zou de nationale staatskas moeten worden aangesproken.

De rechter neemt in de als eerst besproken zaak als uitgangspunt dat het document niet verbindend is. Het College schenkt echter geen aandacht aan de jurisprudentie van het Hof waarin is bepaald dat soft law-handelingen onder omstandigheden een bindende werking kunnen hebben. Vanuit unierechtelijk perspectief bezien had het CBB op zijn minst moeten nagaan of van (enige mate van) bindende werking sprake is. Het is mij overigens niet duidelijk waarom het CBB ter onderbouwing van zijn conclusie verwijst naar de in het document gebezigde bewoordingen. Uit de jurisprudentie van het Hof blijkt immers niet dat het van de gebezigde bewoordingen afhangt of een soft law-handeling bindende werking toekomt; daarvoor is een grondslag of samenwerkingsplicht in Europese hard law nodig. Als eenmaal is vastgesteld dat een soft law-handeling bindende werking heeft, kunnen de bewoordingen wel van invloed zijn op de mate van bindende werking. ${ }^{\mathbf{1 3 9}}$

In de tweede kennelijke fout-zaak gaat de rechter uitgebreider in op de inhoud en de uitlegging van het document. Opvallend is vooral dat het CBB veel waarde hecht aan de intentie van de Europese Commissie die in het Werkdocument doorschemert. De rechter lijkt daarmee te willen inspelen op de bestuurlijke praktijk om zoveel mogelijk in de pas te lopen met de Europese Commissie. De Commissie juicht dit waarschijnlijk toe. Niet alleen het bestuur maar ook de nationale rechter danst naar haar pijpen.

Tot slot is het opvallend dat het Werkdocument door de Nederlandse wetgever niet in wetgeving is neergelegd. Over dit stilzitten van de wetgever zal op Europees niveau niet worden geklaagd. In het algemeen bestaat er immers geen verplichting voor de wetgever om stoft lawhandelingen in wetgeving neer te leggen. Uit de uitspraak blijkt bovendien niet dat in dit specifieke geval voor de wetgever een verplichting bestond om actie te ondernemen (bijvoorbeeld om een regeling op te stellen die in overeenstemming zou moeten zijn met het Werkdocument).

\section{Een vijftig bomen-zaak: casus en context}

Uit artikel 44 lid 1 en 2 van Verordening 1782/2003 volgt dat onder een subsidiabele hectare wordt verstaan alle 'landbouwgrond' van het bedrijf in de vorm van bouwland en blijvend grasland. Artikel 8 van Verordening 796/2004 bepaalt kort gezegd dat ook een perceel met bomen als een perceel landbouwgrond kan worden beschouwd als op dat perceel landbouwactiviteiten kunnen worden verricht. Deze verordeningen vormen het rechtskader in deze zaak, wat betekent dat (wederom) het regime van het EOGFL van toepassing is. Dit rechtskader wordt verder ingevuld door het oriëntatiedocument AGRI/60363/2005-REV1. Artikel 8 van dit document bepaalt: 'overeenkomstig artikel 8 lid 1 van Verordening nr. 796/2004 moeten met bomen beplante oppervlakten (...) binnen een perceel landbouwgrond, met een plantdichtheid van meer dan 50 bomen per hectare, worden beschouwd als oppervlakten die niet voor steun in aanmerking komen. Uitzonderingen kunnen eventueel worden gemaakt voor gemengde teelten (...) en om ecologische en milieutechnische redenen. 
Mogelijke uitzonderingen moeten op voorhand door de lidstaten worden vastgesteld.' Het Oriëntatiedocument is niet door de Commissie gepubliceerd en op het moment van de uitspraak niet in Nederlandse wet- of regelgeving neergelegd.

De Minister wijst, onder verwijzing naar het Oriëntatiedocument, een aanvraag voor bedrijfstoeslag voor een hectare af omdat op de percelen meer dan vijftig bomen per hectare staan. Hij geeft aan het Oriëntatiedocument te hanteren als dwingend voorschrift. Daarbij neemt de Minister in aanmerking dat Nederland geen uitzonderingen heeft vastgesteld op het 50 bomen-criterium. In de procedure staat de vraag centraal of de Minister terecht en op goede gronden de aanvraag heeft afgewezen.

Het College overweegt dat de Minister het karakter van het Oriëntatiedocument miskent door het niet als richtsnoer te hanteren maar als dwingend voorschrift. De omstandigheid dat Nederland geen uitzonderingen heeft vastgesteld, brengt volgens het College niet mee dat het verweerder niet vrij zou staan om tot een individuele beoordeling van de steunwaardigheid van de percelen van appellante over te gaan. Voor een individuele beoordeling bestaat in ieder geval aanleiding als door de landbouwer bijzondere omstandigheden naar voren zijn gebracht, zoals in dit geval de stelling dat de meeste bomen langs de kavelsloten of afrastering staan zodat landbouwmachines zonder problemen hun werk kunnen doen. Het besluit tot afwijzing van de aanvraag is volgens het College ondeugdelijk gemotiveerd.

De vijftig bomen-zaken: beoordeling vanuit unierechtelijk perspectief

Ook in deze zaak wordt de soft law-handeling door de Minister gevolgd. De Minister hanteert het Oriëntatiedocument zelfs als dwingend voorschrift. De reden hiervoor kan net als in de besproken kennelijke fout-zaak met name worden gevonden in de afhankelijkheid van de lidstaat van de Commissie als het gaat om unierechtelijke steun. Als de Minister handelt in lijn met het soft law-document loopt hij het minste risico de steun uit eigen zak te moeten betalen. Doordat het CBB voor deze opstelling van het bestuur een stokje steekt, loopt de Minister nu alsnog het risico voor de steun te moeten opdraaien. Immers, de kans bestaat dat de Commissie met de afwijking van het vijftig bomen-criterium niet akkoord gaat, zeker nu de afwijking niet in een van te voren vastgestelde uitzondering is neergelegd.

Interessant is verder dat het CBB het Werkdocument bestempeld als een 'aanbeveling van de Commissie waaraan niet de status van een wettelijke voorschrift kan worden toegekend'. Net als in de kennelijke fout-zaken gaat het CBB voorbij aan de jurisprudentie van het Hof betreffende bindende werking van administratieve soft law-handelingen. Een samenwerkingsplicht lijkt wel aanwezig, omdat de uitvoeringsverordening van het EOGFL waaraan het Werkdocument gelieerd is, voorziet in een geïntegreerd beheers- en controlesysteem dat stoelt op een nauwe samenwerking tussen de lidstaten en de Commissie. Uit de uitspraak blijkt echter niet dat het Oriëntatiedocument (expliciet) door Nederland is aanvaard.

Als de uitspraak op dit moment zou zijn gewezen, zou dit anders zijn. Het vijftig bomencriterium is inmiddels aanvaard doordat deze is neergelegd in de Regeling GLB-inkomenssteun 2006. ${ }^{\mathbf{1 4 0}}$ Dit betekent dat als deze zaak nu had gespeeld het vijftig bomen-criterium een bindende werking zou hebben. Deze bindende werking van het Oriëntatiedocument speelt echter in de praktijk niet in de eerste plaats een rol, omdat de Regeling waarin het criterium is neergelegd reeds juridisch verbindend is. Door de Commissie zal het overigens worden toegejuicht dat het criterium in nationale regelgeving is neergelegd.

\section{Een interpretatienota-zaak: casus en context}

Artikel 6 van Verordening 1254/1999 van de Raad houdende een gemeenschappelijke ordening der markten in de sector rundvlees, bepaalt dat aan producenten die zoogkoeien houden, op hun verzoek een premie voor het aanhouden van zoogkoeien kan worden verleend. ${ }^{\mathbf{1 4 1}}$ Het gaat in deze zaak om premies die worden gefinancierd uit het Europees Oriëntatie- en Garantiefonds voor de Landbouw - Afdeling Garantie. ${ }^{142}$

In artikel 23 lid 4 van de Uitvoeringsverordening 2342/1999 van de Commissie is een minimumpercentage voor het gebruik van premierechten neergelegd. ${ }^{\mathbf{1 4 3}}$ Het tweede lid van artikel 23 bepaalt dat als een producent niet tenminste van het minimumpercentage van zijn 
rechten gebruik maakt, het niet gebruikte deel aan de nationale reserve wordt overgedragen, behalve (onder meer) in uitzonderlijke, naar behoren gemotiveerde gevallen. In de Interpretatienota's 26 en 51 worden voorbeeldsituaties geschetst waarin sprake is van een uitzonderlijk, naar behoren gemotiveerd geval. De Interpretatienota's zijn niet gepubliceerd. ${ }^{\mathbf{1 4 4}}$ Eén van de rechtsvragen in het geschil is of van een uitzonderlijk, naar behoren gemotiveerd geval sprake is. Verweerder laat zich bij de beantwoording van deze vraag hoofdzakelijk leiden door de Interpretatienota's 26 en 51 . Hij stelt zich op het standpunt dat van een uitzonderlijk, naar behoren gemotiveerd geval geen sprake is.

Volgens het College behelzen de Interpretatienota's 'naar hun aard' geen bindende regels. Zij hebben alleen betrekking op enkele voorgelegde voorbeeldsituaties. Het College acht het daarom aanvaardbaar dat de interpretatienota's als richtsnoer worden gehanteerd. Verweerder heeft echter 'een eigen verantwoordelijkheid om aan de hand van de feiten en de omstandigheden van het geval te beoordelen of sprake is van een 'uitzonderlijk, naar behoren gemotiveerd geval".

Het College concludeert dat een deel van de niet-gebruikte premierechten ten onrechte aan de nationale reserve is toegevoegd. Het College komt tot deze conclusie door zich te baseren op het eerste en derde in Interpretatienota nr. 51 genoemde voorbeeld. Verweerder had moeten vaststellen dat sprake is van een uitzonderlijk, naar behoren gemotiveerd geval als bedoeld in artikel 23 tweede lid van Verordening 2343/1999, aldus het College.

De interpretatienota-zaken: beoordeling vanuit unierechtelijk perspectief

In het oog springt dat het bestuur, net als het geval was in de hiervoor geanalyseerde zaken, de Interpretatienota's van de Commissie strikt volgt. Er kan mijns inziens echter van worden uitgegaan dat de Interpretatienota's geen bindende werking hebben. Weliswaar zou van een samenwerkingsverplichting kunnen worden gesproken (de zoogdierpremie vloeit immers voort uit een nauw samenwerkingsverband in het kader van 'gemengd' bestuur, het EOGFL-G) maar het lijkt niet dat de Interpretatienota's expliciet door de Nederlandse regering zijn aanvaard. De interpretatienota's vormen namelijk een reactie van de Commissie op verschillende vanuit Spanje en het Verenigd Koninkrijk (dus niet vanuit Nederland) voorgelegde hypothetische gevallen. ${ }^{145}$

Het CBB acht het niet aanvaardbaar dat het bestuur de Interpretatienota's strikt volgt. Het verlangt dat de Minister een individuele beoordeling maakt. Dit lijkt in overeenstemming met het doel van de Interpretatienota's te zijn waarin slechts voorbeelden worden genoemd van situaties waarin sprake is van een uitzonderlijk, naar behoren gemotiveerd geval. De rechter had echter, zoals ook in de andere zaken het geval is, beter moeten motiveren waarom de Interpretatienota's geen bindende werking hebben.

In de uitspraak komt verder naar voren dat het volgen van de Interpretatienota's voor het bestuur een zelfbindende werking heeft. Het CBB komt namelijk aan de hand van de Interpretatienota's tot de conclusie dat de Minister tot een verkeerde beslissing is gekomen. De Minister werkt zich in de nesten door de nota's te volgen, maar deze in de ogen van het CBB niet op de juiste manier uit te leggen. Een deel van de premierechten is daardoor onterecht aan de staatskas toegevoegd.

Overigens had het CBB de Interpretatienota's ook in aanmerking moet nemen in het geval de Minister de Nota's niet als leidraad zou hebben gehanteerd. Volgens de Grimaldi-uitspraak zijn de soft law-handelingen voor het CBB een verplicht hulpmiddel zijn ter interpretatie van Europese hard law-regels. ${ }^{\mathbf{1 4 6}}$ Het CCB lijkt echter de Interpretatienota's bij zijn beslissing in aanmerking te nemen omdat de Minister heeft aangegeven de Interpretatienota's te volgen. ${ }^{\mathbf{1 4 7}}$

\section{Europese administratieve soft law in het licht van het Nederlandse legaliteitsbeginsel}

In de vorige paragrafen zijn de Europese eisen ten aanzien van de doorwerking van administratieve soft law in de lidstaten in kaart gebracht en is onderzocht hoe in de Nederlandse rechtspraktijk met Europese administratieve soft law wordt omgegaan. In deze paragraaf wordt de doorwerking van administratieve soft law geanalyseerd en beoordeeld in het licht van het Nederlandse legaliteitsbeginsel. 


\subsection{Het Nederlandse legaliteitsbeginsel en Europese administratieve soft law}

De term legaliteit betekent letterlijk 'wetmatigheid'. Het beginsel ziet in essentie op de binding van het bestuur aan de wet. ${ }^{\mathbf{1 4 8}}$ In Nederland wordt het legaliteitsbeginsel vooral begrepen als het vereiste dat (in ieder geval) eenzijdig verplichtend overheidsoptreden op een wettelijke grondslag dient te berusten. ${ }^{\mathbf{1 4 9}}$

Volgens de functionele benadering van Voermans is het legaliteitsbeginsel 'een middel tot een doel' $^{\prime}{ }^{150}$ Het oorspronkelijke doel van het legaliteitsbeginsel is het bieden van bescherming aan de burgers tegen de macht van de overheid. ${ }^{\mathbf{1 5 1}}$ De overheid kan niet verder ingrijpen in de vrijheid van de burgers dan door de wet is toegestaan.

Uit deze beschermingsfunctie vloeien de legitimerende functie en de rechtszekerheidsfunctie voort. Het legaliteitsbeginsel heeft een legitimerende functie omdat een wettelijke bepaling zorgt voor input-legitimiteit, throughput-legitimiteit en output-legitimiteit. ${ }^{\mathbf{1 5 2}}$ Inputlegitimiteit refereert aan de (indirecte) betrokkenheid van burgers bij de besluitvorming, in het geval van een wet via representatie door gekozen volksvertegenwoordigers. ${ }^{\mathbf{1 5 3}}$ Throughputlegitimiteit verwijst naar het besluitvormingsproces. De wet genereert throughput-legitimiteit omdat de wet het resultaat is van een openbare uitwisseling van argumenten en tot stand komt volgens een van te voren vastgestelde, transparante procedure. ${ }^{\mathbf{1 5 4}}$ Output-legitimiteit wordt gegenereerd doordat de wet mogelijkheden schept om op een effectieve manier te besturen en om oplossingen te vinden voor problemen die niet door individuele actie kunnen worden opgelost. ${ }^{155}$ De wet bevordert tot slot rechtszekerheid doordat de wet voor iedereen kenbaar is, het overheidsoptreden voorspelbaar maakt en duidelijkheid geeft over rechtsposities. ${ }^{\mathbf{1 5 6}}$ Volgens het Nederlandse legaliteitsbeginsel, gedefinieerd als het vereiste dat eenzijdig verplichtend overheidsoptreden moet berusten op een wettelijke grondslag, lijkt met Europese administratieve soft law niet veel mis. ${ }^{\mathbf{1 5 7}} \mathrm{Soft}$ law-handelingen roepen immers geen verplichtingen in het leven waarin niet is voorzien door de Verdragen. Als dit wel het geval is, steekt het Hof van Justitie voor deze 'onechte' soft law een stokje. De soft law-handeling is volgens het Hof dan onrechtmatig. ${ }^{158}$

In het oog moet echter worden gehouden dat het vereiste van het Nederlandse legaliteitsbeginsel is toegesneden op de Nederlandse rechtsorde, terwijl Europese administratieve soft law fungeert in een geïntegreerde rechtsorde. Om Europese administratieve soft law in het licht van het Nederlandse legaliteitsbeginsel te kunnen beoordelen, moet dit beginsel eerst worden afgestemd op de Europese context. Hierna bezie ik of de doelen die het legaliteitsbeginsel dient in nationale context een andere inkleuring krijgen in Europese context.

De beschermingsfunctie krijgt in unierechtelijk perspectief een extra dimensie. De Nederlandse burger moet nu ook worden beschermd tegen de macht van de Europese Unie. Tussen de Europese Unie en de burger zit bovendien nog een tussenlaag: de lidstaten. ${ }^{\mathbf{1 5 9}}$ Ook de lidstaten moeten tegen de macht van de Unie worden beschermd. Immers, de Unie mag niet meer macht uitoefenen dan de lidstaten aan haar hebben overgedragen. Het Europese hard law-systeem is gebaseerd op dit attributiebeginsel. ${ }^{\mathbf{1 6 0}}$ De Europese Unie mag alleen hard law-regels aannemen als zij daartoe aan de Verdragen de bevoegdheid ontleent. ${ }^{\mathbf{1 6 1}}$

De macht die de Europese Unie uitoefent over de burgers van de lidstaten en over de lidstaten zelf, dient voorts legitiem te zijn. De Unie oefent voornamelijk 'macht' uit door maatregelen op te leggen die verplichtingen voor burgers inhouden en/of bindend zijn voor de lidstaten. Vooral van deze verplichtende en bindende maatregelen dient daarom een sterk legitimerend effect uit te gaan. Een unierechtelijke maatregel is legitiem als de maatregel, net zoals een wettelijke bepaling, input-, throughput- en output-legitimiteit genereert. ${ }^{\mathbf{1 6 2}}$ Naast dit normatieve kader, moet in het oog worden gehouden dat van legitimiteit pas sprake is als het EU-bestuur daadwerkelijk door de lidstaten en de burgers wordt aanvaard. De afgelopen tien jaar is de legitimiteit van de Europese Unie voortdurend onderwerp geweest van discussie. ${ }^{\mathbf{6 3}}$ In de lidstaten is een tendens zichtbaar waarin eurosceptische (politieke) bewegingen opkomen en steeds meer aanhang krijgen binnen de bevolking. De legitimerende functie treedt in Europese context meer op de voorgrond dan in nationale context.

Tot slot krijgt ook de rechtszekerheidsfunctie in unierechtelijke context een veellagig karakter. Zo moeten unierechtelijke voorschriften gericht aan nationale autoriteiten ook voor burgers 
kenbaar zijn. Als dit niet het geval is, is het optreden van de nationale overheid voor de burger niet voorspelbaar en ontstaat onduidelijkheid over rechtsposities.

Geconcludeerd kan worden dat het Nederlandse legaliteitsbeginsel in Europese context dezelfde doelen dient als in nationale context, maar dat deze doelen in Europese context een veellagige inkleuring hebben.

\subsection{Europese administratieve soft law in het licht van het Nederlandse legaliteitsbeginsel in een Europees jasje}

Hierna bezie ik in hoeverre de drie hiervoor besproken doelen van het legaliteitsbeginsel met Europese administratieve soft law zijn gediend. Met deze zoektocht zullen de knelpunten (als deze er zijn) die zich bij de doorwerking van Europese administratieve soft law in de nationale rechtsorde voordoen, zichtbaar worden.

\subsubsection{Bescherming}

Europese administratieve soft law heeft, vanuit beschermingsoogpunt bezien, veel voordelen. Soft law is nodig om het Unierecht op een consistente en transparante wijze door de lidstaten te laten toepassen. Zonder de aanwezigheid en het gebruik van soft law-handelingen ligt willekeur, of in ieder geval de schijn van willekeur, op de loer.

Er is echter een andere kant van de medaille. Aan het gebruik van soft law-handelingen kleeft het gevaar dat de Commissie buiten de bevoegdheden treedt die haar door het hard lawsysteem zijn toegekend. Zeker omdat administratieve soft law vaak een bindende werking genereert, is dit problematisch. De Commissie kan door middel van soft law de grenzen oprekken en nieuwe verplichtingen binnensmokkelen. ${ }^{\mathbf{1 6 4}}$ Met deze 'sluikse manier van besluitvorming ${ }^{\mathbf{1 6 5}}$ is de bescherming van de lidstaten en van de burgers tegen de macht van de Unie niet gediend.

Ook als de Commissie binnen haar bevoegdheidskaders blijft, kan het gebruik van soft lawhandelingen problematisch zijn. Het uitwerken van Europese regelgeving om deze te kunnen implementeren is in beginsel een taak van de lidstaten. ${ }^{\mathbf{1 6 6}}$ Dit is alleen anders als de Commissie door de Raad wordt gemachtigd om nadere regels te stellen ten aanzien van de implementatie van het Unierecht (dan is sprake van een zogenaamde uitvoeringshandeling, zie artikel 291 VWEU). ${ }^{\mathbf{1 6 7}}$ Als de Commissie deze ruimte ook kan invullen door voor de lidstaten bindende soft law-handelingen aan te nemen, neemt zij sluipenderwijs de touwtjes van de lidstaten in handen. De relatie tussen de Europese Unie en de lidstaten komt onder spanning te staan.

Toch is hiermee de conclusie nog niet gegeven. Eerst moet worden nagegaan in hoeverre deze beschermingsproblemen worden gecompenseerd door rechtsbeschermingsmogelijkheden op Europees en/of nationaal niveau.

Voor het gevaar dat de Commissie via soft law verplichtingen 'binnensmokkelt', wordt door het Europese Hof gewaakt. ${ }^{\mathbf{1 6 8}}$ Tegen een soft law-handeling in een hard law-jasje staan twee wegen open: de weg van het nietigheidsberoep van artikel 263 VWEU en de weg van de prejudiciële procedure. Het Hof ziet er op toe dat met Europese administratieve soft law verplichtingen worden gecreëerd die niet vallen binnen een hard law-verplichting. ${ }^{\mathbf{1 6 9}}$ Echter, deze controle is niet optimaal. De controle door het Hof is namelijk een controle achteraf, en bovendien ziet het Hof alleen zaken die aan haar worden voorgelegd. ${ }^{\mathbf{1 7 0}}$

Als sprake is van een soft law-handeling die geen nieuwe verplichtingen in het leven roept, zijn de mogelijkheden om deze handeling rechtstreeks aan te vechten echter beperkt. De weg van artikel 263 VWEU is afgesloten. Volgens de terminologie van dit artikel, waar het Hof strikt aan vasthoudt, kan immers alleen een beroep tot nietigverklaring worden ingesteld tegen handelingen die beogen rechtsgevolgen ten aanzien van derden te hebben. ${ }^{\mathbf{1 7 1}}$ Ook ten aanzien van prejudiciële geldigheidsvragen van de nationale rechter die betrekking hebben op een soft law-handeling stelt het Hof zich terughoudend op. Dit blijkt onder meer uit de zaken Wagner en Algemene Scheepsagentuur ${ }^{\mathbf{1 7 2}}$ waarin het Hof de beantwoording van geldigheidsvragen ontwijkt door deze vragen om te buigen tot interpretatievragen. ${ }^{\mathbf{1 7 3}}$

Tegenover de beperkte mogelijkheden om de geldigheid van soft law-handelingen aan te 
vechten, staat dat ten aanzien van beschikkingen die (mede) op basis van een soft lawhandeling worden aangenomen de wegen van artikel 263 en 267 VWEU wel openstaan. ${ }^{\mathbf{1 7 4}}$ Bovendien is het mogelijk om in een procedure de exceptie van onwettigheid tegen een soft law-handeling in te roepen. ${ }^{\mathbf{1 7 5}}$ Met deze exceptie kan worden bereikt dat een soft lawhandeling in een concrete procedure niet-toepasselijk wordt verklaard. ${ }^{176}$ Deze verklaring heeft tot gevolg dat aan de beschikking de rechtsgrondslag wegvalt. De geldigheid van de soft lawhandeling wordt daarmee echter niet aangetast. ${ }^{177}$

Toch kan het problematisch zijn dat tegen soft law-handelingen niet rechtstreeks bij het Hof kan worden opgekomen en dat het Hof zich terughoudend opstelt ten aanzien van prejudiciële geldigheidsvragen. Met name als een soft law-handeling voor een lidstaat een sterk bindende werking heeft, heeft de lidstaat er belang bij de geldigheid van soft law-handelingen te kunnen aanvechten. Dit is ook het geval als de Commissie zich zijdelings door soft law-handelingen laat leiden bij de beslissing om een infractieprocedure te starten. ${ }^{\mathbf{1 7} 8}$

Ook een adequate rechtsbescherming van particulieren lijkt met de huidige situatie in het geding te komen, met name doordat onduidelijkheid en onzekerheid rondom de verenigbaarheid, het rechtskarakter en de status van soft law-handelingen bestaat. ${ }^{\mathbf{1 7 9}}$ Nationale rechters worden niet gestimuleerd om prejudiciële geldigheidsvragen te stellen, gezien de ontwijkende opstelling van het Hof ten aanzien van geldigheidsvragen over administratieve soft law-handelingen. Bovendien laat de huidige praktijk het beeld zien dat nationale rechters vaak ervoor kiezen de lijn van de (deskundige) Commissie volgen. De rechters lijken niet snel geneigd diepgaand onderzoek te doen naar de verenigbaarheid, de status of het rechtskarakter van soft law-handelingen.

\subsubsection{Legitimiteit}

Omdat van Europese administratieve soft law-handelingen in mindere of meerdere mate een bindende werking naar de lidstaten uitgaat, dient van het gebruik van deze handelingen een legitimerend effect uit te gaan. Dit is zeker nodig als sprake is van een sterk bindende werking, omdat de ruimte die de lidstaten hebben om het Unierecht toe te passen, dan grotendeels door de Commissie wordt ingevuld. Ook in het licht van de al vaak geconstateerde legitimiteitsproblemen waar de Unie mee kampt, is een legitimerende werking van administratieve soft law wenselijk.

In hoeverre genereert Europese administratieve soft law legitimiteit? In de eerste plaats genereert Europese administratieve soft law zogenaamde 'output-legitimiteit'. Deze outputlegitimiteit wordt gegenereerd doordat Europese administratieve soft law noodzakelijk is voor een uniforme en effectieve toepassing van Europese hard law. Europese administratieve soft law bevordert rechtszekerheid, rechtsgelijkheid en een consistente en transparantie bestuursvoering. In de vorige paragraaf is echter gebleken dat met Europese administratieve soft law deze doelen in de praktijk niet vanzelfsprekend zijn vervuld.

Soft law-handelingen generen enige mate van input-legitimiteit en throughput-legitimiteit via de hard law-handeling waaraan zij verbonden zijn. Bij soft law-handelingen die via een rechtsgrondslag in hard law een bindende werking genereren, is deze 'indirecte' legitimiteit vrij sterk.

Van de totstandkoming van soft law-handelingen zelf gaat echter weinig input- en throughputlegitimiteit uit. Het Europese parlement speelt bij de totstandkoming van Europese administratieve soft law, in ieder geval formeel, geen rol. Lidstaten zijn soms bij de totstandkoming betrokken, maar meestal is het niet duidelijk wat hun rol precies is. De onderhandelingen vinden plaats achter gesloten deuren. Voorts is de besluitvormingsprocedure niet van te voren vastgelegd. De Verdragen zwijgen, zo is in paragraaf twee gebleken. Het debat waarin soft law tot stand komt is niet openbaar. Geconcludeerd kan worden dat van Europese administratieve soft law een onvoldoende legitimerende werking uitgaat. De output-legimiteit en indirect gegenereerde input- en throughput-legitimiteit zijn niet voldoende om het gebruik van soft law te rechtvaardigen. Door te sturen met onvoldoende gelegitimeerde soft law-handelingen in een klimaat waarin euroscepticisme toeneemt en de Europese Unie met legitimiteitsproblemen kampt, begeeft de Commissie zich op glad ijs. 


\subsubsection{Rechtszekerheid}

Vooropgesteld zij dat het doel van soft law-handelingen is om rechtszekerheid te creëren ten aanzien van de uitleg en de toepassing van Europese hard-law. In de meeste gevallen zullen soft law-handelingen in dit opzicht ook daadwerkelijk voor rechtszekerheid zorgen. Tegelijkertijd zorgen soft law-handelingen echter ook voor rechtsonzekerheid.

Rechtsonzekerheid wordt in de eerste plaats veroorzaakt door het bestaan van onduidelijkheid over het rechtskarakter (en dan met name over de mate van bindende werking) van soft lawhandelingen. Zelfs voor de ervaren jurist is het niet gemakkelijk om in het doolhof van Europese regelingen, de jurisprudentie en de praktijk de weg te vinden naar het rechtskarakter van soft law-handelingen. De nationale rechter, wetgever en bestuursorganen krijgen geen duidelijke aanwijzingen uit Brussel en varen dus op hun eigen kompas. ${ }^{\mathbf{1 8 0}}$ Dit zorgt voor een verwarrende en onoverzichtelijke situatie.

De tweede oorzaak van de rechtsonzekerheid is dat veel soft law-handelingen niet worden gepubliceerd. ${ }^{181}$ Dit leidt ertoe dat burgers vaak niet van soft law-bepalingen op de hoogte zijn en zelfs niet kunnen zijn. De op soft law gebaseerde gedragslijn van lidstaten is hierdoor voor veel burgers niet zichtbaar, en daarmee is het overheidsoptreden onvoorspelbaar.

Aldus is het derde doel van het legaliteitsbeginsel, rechtszekerheid, met Europese administratieve soft law niet vervuld.

\subsection{Conclusie}

Uit het voorgaande volgt dat Europese administratieve soft law in veel opzichten met de beginselen van bescherming tegen de overheid, legitimiteit en rechtszekerheid op gespannen voet staat. Bij de bespreking van de beginselen is naar voren gekomen welke knelpunten zich bij de doorwerking van administratieve soft law voordoen in de Nederlandse rechtsorde. In de eerste plaats manifesteert zich op nationaal niveau een (rechts)beschermingsprobleem. Met Europese administratieve soft law bestaat het gevaar dat de Commissie buiten haar bevoegdheidspaden treedt en nieuwe verplichtingen in het leven roept. Het Hof zorgt voor rechtsbescherming als de Commissie buiten haar bevoegdheidspaden treedt, maar omdat het Hof alleen zaken onder ogen krijgt die haar worden voorgelegd, en deze controle retrospectief van aard is, is van een voldoende beschermingsmechanisme tegen de macht van de Unie geen sprake. Ook de nationale rechter kan een controlerende taak moeilijk vervullen aangezien hij zich geconfronteerd ziet met een terughoudend Hof als het gaat om geldigheidsvragen. Tot slot zijn de mogelijkheden om soft law-handelingen rechtstreeks aan te vechten beperkt.

In de tweede plaats wordt met Europese administratieve soft law het legitimiteitsprobleem van de Europese Unie vergroot. Doordat van veel soft law-handelingen een juridische of feitelijke bindende werking uitgaat, werkt het veelvuldig gebruik van administratieve soft law in de hand dat op nationaal niveau het beeld ontstaat dat de Commissie via controversiële wegen haar macht over de lidstaten (en dus over de burgers) probeert uit te breiden.

In de derde plaats leidt Europese administratieve soft law op nationaal niveau tot rechtsonzekerheid. Niet alleen doordat de documenten vaak niet zijn gepubliceerd, (niet op Europees niveau en niet door de nationale autoriteiten), maar ook doordat onduidelijkheid bestaat over het rechtskarakter van soft law.

\section{>5 Oplossingsrichtingen}

Europese administratieve soft law kan in het licht van het Nederlandse legaliteitsperspectief vaak niet door de beugel, zo is in de vorige paragraaf geconcludeerd. In deze paragraaf ga ik op zoek naar oplossingsrichtingen die Europese administratieve soft law met de doelen van het legaliteitsbeginsel op één lijn kunnen brengen. Ik zoek deze oplossingsrichtingen eerst op het niveau van de Europese Unie en vervolgens op nationaal niveau.

\subsection{Oplossingsrichtingen op het niveau van de Europese Unie}

De Europese oplossing om de drie doelen van het legaliteitsbeginsel te realiseren, lijkt voor de 
hand te liggen. Het klassieke 'legaliteitsmiddel', een wettelijke regel, moet worden ingezet. De soft law-handelingen zouden in hard law moeten worden omgezet. Hierna bezie ik of dit inderdaad de juiste oplossing is en, als dit niet het geval is, welke alternatieve maatregelen dan kunnen worden getroffen.

\subsubsection{Een transformatie van soft law in hard law?}

Met de transformatie van Europese administratieve soft law in Europese hard law zou het legitimiteitsprobleem voor een groot deel zijn opgelost. Een hard law-handeling genereert een sterk legitimerend effect. De hard law-handeling komt tot stand via een vooraf vastgestelde, kenbare procedure en bij de besluitvorming zijn leden uit het Europese Parlement betrokken. ${ }^{182}$

Ook de rechtszekerheid wordt met een hard law-regeling bevorderd. Het is duidelijk wat de juridische status is van een hard law-handeling. Immers, zowel in het geval van een verordening als in het geval van een richtlijn is sprake van verbindendheid voor de lidstaat. ${ }^{\mathbf{1 8 3}}$ Burgers en nationale autoriteiten behoeven niet meer te gissen naar de juridische effecten van soft law-handelingen. Bovendien wordt rechtszekerheid gecreëerd doordat hard lawhandelingen altijd worden gepubliceerd in het publicatieblad van de Europese Unie. Ook de bescherming van de burger en de lidstaat tegen de Europese Unie is met hard law gediend. De instellingen mogen alleen hard law-handelingen aannemen als de EU-Verdragen daartoe toestemming geven. Minder dan bij soft law-handelingen bestaat het gevaar dat de Europese Unie buiten haar bevoegdheden treedt.

Bovendien, als soft law-handelingen worden getransformeerd in hard law-handelingen, staan ook meer rechtsbeschermingsmogelijkheden open. Hard law-handelingen zijn verbindend voor de lidstaten, en sorteren (dus) juridische effecten. Het nietigheidsberoep van artikel 263 VWEU staat open en de nationale rechter zal eerder ontvankelijk worden verklaard met een prejudiciële geldigheidsvraag.

Een transformatie van soft law in hard law lijkt gezien het voorgaande de ideale oplossing. Aan de drie doelen van het legaliteitsbeginsel is voldaan. Toch is het transformeren van soft law in hard law in mijn ogen niet de juiste oplossing, omdat aan deze transformatie grote nadelen zijn verbonden.

Door soft law-handelingen in hard law om te zetten gaat in de eerste plaats het 'zachte' karakter van deze handelingen verloren. $\mathrm{Nu}$ hebben de lidstaten vaak, ook al is sprake van bindende werking, nog wel de mogelijkheid om gemotiveerd van de soft law-handelingen af te wijken als dat nodig is in de specifieke omstandigheden van hun nationale uitvoeringspraktijken. Het neerleggen van soft law in hard law-handelingen werkt een rigide systeem in de hand, waarin de lidstaten nog minder 'bewegingsruimte' hebben.

Niet alleen voor de lidstaten, maar ook voor de instellingen van de Europese Unie geeft Europese administratieve soft law ruimte voor flexibiliteit. Een soft law-handeling is veel gemakkelijker en sneller te wijzigen dan een hard law-handeling. Voor het aannemen van een soft law-handeling is het niet nodig dat een wetgevingsprocedure wordt doorlopen. De Commissie kan zo beter en sneller inspelen op de actualiteit.

Bovendien is het simpelweg onuitvoerbaar om alle law-handelingen in een hard law-bepaling neer te legen. De Commissie, het Parlement en de Raad zouden dan nog zwaarder worden belast dan nu al het geval is. De berg aan Europese regelgeving zou nog groter worden. Uit het voorgaande volgt dat het doel dat met soft law-handelingen wordt gediend, niet met hard law-handelingen kan worden bereikt. Mijn conclusie is dan ook dat soft law-handelingen niet in hard law-handelingen kunnen worden omgezet om de spanning met het Nederlandse legaliteitsbeginsel weg te nemen.

\subsubsection{Een einde aan de bindende werking van administratieve soft law?}

Is de oplossing dan misschien gelegen in het ontnemen van elke vorm van bindende werking aan soft law-handelingen? Als van een soft law-handeling geen bindende werking uitgaat, is het niet problematisch als van de handeling geen sterk legitimerend effect uitgaat omdat de lidstaten dan hun vrijheid behouden. Ook zou rechtsonzekerheid worden weggenomen, omdat duidelijkheid wordt geschapen over het rechtskarakter van administratieve soft law. ${ }^{\mathbf{1 8 4}}$ Tot slot 
lijkt de afwezigheid van bindende werking ook aantrekkelijk in het licht van de bescherming van de lidstaten tegen de macht van de Europese Unie. De Unie kan dan niet meer via soft lawhandelingen verplichtingen 'binnensmokkelen'. Niet-bindende soft law roept aldus in het licht van het legaliteitsbeginsel geen problemen op. Het middel van een wettelijke bepaling behoeft niet te worden ingezet.

Toch is ook het ontnemen van iedere bindende werking aan soft law-handelingen mijns inziens niet de juiste oplossing. In de eerste plaats is enige mate van bindende werking van soft lawhandelingen nodig voor het goed functioneren van de Europese Unie. Administratieve soft law dient om de 27 lidstaten het Unierecht op uniforme wijze te laten toepassen en implementeren. ${ }^{\mathbf{1 8 5}}$ Deze uniformiteit komt ook de rechtsgelijkheid van de burgers in de lidstaten ten goede. Als soft law-handelingen geen enkel bindend effect genereren, zullen lidstaten geneigd zijn hun eigen plan te trekken. Het gewenste effect wordt dan niet bereikt. In de tweede plaats, als al bereikt zou kunnen worden dat soft law-handelingen geen juridisch bindende effecten generen, is het zeer de vraag of het mogelijk is te bewerkstelligen dat deze handelingen ook de facto hun bindende werking voor de lidstaten verliezen. In veel gevallen zal de afhankelijkheid van de lidstaten van de Commissie, zoals op het terrein van de Europese subsidies, immers blijven bestaan.

Bovendien kan het verzet tegen een bindende werking van soft law-handelingen worden gezien als roeien tegen de stroom in. Administratieve soft law is namelijk een 'new governanceinstrument' en maakt deel uit van de 'new governance-trend'. New governance is een nieuwe manier van besturen die afstand neemt van het traditionele model dat uitgaat van sturing door middel van bindende besluiten die worden genomen door gekozen

volksvertegenwoordigers. ${ }^{\mathbf{1 8 6}}$ Niet alleen in de Europese Unie, maar ook in andere transnationale verbanden is new governance in toenemende mate zichtbaar. Ook het de facto bindende karakter van new governance-normen is geen onbekend fenomeen. Scheltema noemt het 'verbazingwekkend hoe snel ook zonder enige wettelijke of internationaalrechtelijke grondslag voorschriften ontstaan die in feite een dwingend karakter hebben'. ${ }^{\mathbf{1 8}} \mathbf{7}$ In het licht van de new governance-trend is het te verwachten dat het gebruik van Europese administratieve soft law-handelingen zal toenemen en dat het de facto-verbindende karakter van de handelingen er niet snel minder op zal worden.

\subsubsection{Soft law en een bindende werking: een alternatieve route}

Hiervoor is geconcludeerd dat de oplossing voor het legaliteitsprobleem niet is gelegen in het omzetten van soft law in hard law of in het ontnemen van bindende werking aan soft law. Dit betekent dat op zoek moet worden gegaan naar maatregelen waarmee de doelen van het legaliteitsbeginsel worden vervuld en een bindende werking van soft law kan blijven uitgaan. Ik baseer mij hierna rechtstreeks op de drie doelen die het legaliteitsbeginsel dient, en bezie vervolgens welke middelen het beste ingezet kunnen worden om die doelen te bereiken. Ik houd daarbij niet strikt vast aan het uitgangspunt dat het middel het karakter moet hebben van een wettelijke bepaling, maar kijk ook naar andere maatregelen die een vergelijkbaar effect sorteren. Dit is mijns inziens geoorloofd omdat het legaliteitsbeginsel een middel is tot een doel, en geen doel op zich. ${ }^{\mathbf{1 8 8}}$ De voorstellen die ik hierna doe zijn niet in details uitgewerkt. Geprobeerd wordt slechts om mogelijke oplossingsrichtingen in kaart te brengen.

\section{Legitimiteit}

Hiervoor is besproken dat met name van de totstandkoming van Europese administratieve soft een gering legitimerend effect uitgaat. Europese administratieve soft law zou meer input- en througput-legitimiteit moeten genereren. Input-legitimiteit kan in de eerste plaats worden gegenereerd door het Europese Parlement te betrekken bij de totstandkoming van administratieve soft law. De Commissie zou een ontwerp soft law-handeling ter consultatie kunnen voorleggen aan het Europese parlement. Hiervoor heeft overigens ook het Europese parlement zelf gepleit in zijn resolutie over de institutionele en juridische gevolgen van het gebruik van "soft-law" instrumenten. ${ }^{\mathbf{8 9}}$

In de tweede plaats zouden ook (vertegenwoordigers van) de lidstaten bij de totstandkoming van Europese administratieve soft law kunnen worden ingeschakeld. Betrokkenheid van de 
lidstaten heeft immers een sterk legitimerend effect. Daarbij maakt deze betrokkenheid het mogelijk dat de lidstaten ervoor kunnen waken dat de Commissie niet buiten haar bevoegdheden treedt. ${ }^{\mathbf{1 9 0}}$ De betrokkenheid van de lidstaten is dus ook van belang in het licht van het beschermingsbeginsel.

Ik stel voor dat het ontwerp van de Commissie, voordat het naar het Europese parlement wordt gestuurd, wordt voorgelegd aan vertegenwoordigers van de lidstaten. Gedacht kan worden aan een soortgelijk systeem als het systeem van 'comitologie', waarin comités, bestaande uit lidstatelijke vertegenwoordigers, de Commissie ondersteunen bij het vaststellen van uitvoeringsregels. ${ }^{191}$ Deze ondersteuning heeft een vergaand karakter: de comités kunnen zelfs de inhoud van de regelingen bepalen en de totstandkoming van de regelingen dwarsbomen. ${ }^{\mathbf{1 9 2}}$ Lidstatelijke vertegenwoordigers, verenigd in comités, zouden in vergelijkbare zin een bijdrage kunnen leveren aan de totstandkoming van soft law-handelingen. ${ }^{193}$ Welke rol deze comités precies moeten spelen, moet nader worden uitgedacht. Ik denk aan een procedure waarin de comités niet alleen een adviserende rol hebben, maar waarin zij ook wijzigingen kunnen aanbrengen in het voorstel van de Commissie. Als het gaat om soft law-handelingen die een sterk bindende werking hebben, zouden de lidstaten zelfs de mogelijkheid moeten krijgen om een niet-aanvaardbaar uit te spreken over de definitieve versie. ${ }^{\mathbf{9 4}}$ Dit betekent dat de soft lawhandeling voor die lidstaat geen bindende werking heeft. ${ }^{195}$

Voor soft law-handelingen waar een gematigd bindende werking van uitgaat, bijvoorbeeld handelingen ten aanzien waarvan is bepaald dat zij 'in aanmerking moeten worden genomen', is een veto niet nodig omdat inherent aan deze vorm van bindende werking is dat de lidstaten gemotiveerd kunnen afwijken.

In de derde plaats dient de hierboven beschreven procedure transparant te zijn. Ook transparantie genereert immers throughput-legitimiteit. ${ }^{\mathbf{1 9 6}}$ Dit betekent dat naar buiten toe duidelijkheid moet worden geschapen over de verschillende stappen in de procedure, maar ook over de rol die de verschillende actoren (de Commissie, het Parlement, en de comités) in de procedure spelen. ${ }^{\mathbf{1 9 7}}$ Ook dient het debat waarin over de inhoud van de soft law-handelingen wordt onderhandeld zoveel mogelijk openbaar te zijn. Vooral ten aanzien van het debat in de comités zal verder moeten worden nagedacht over de vraag hoe deze openbaarheid te realiseren. Gedacht kan worden aan de mogelijkheid dat een verslag van het debat in de Comités naar het Europese Parlement en de nationale parlementen wordt gestuurd.

\section{Rechtszekerheid}

Rechtszekerheid kan in de eerste plaats worden gecreëerd door duidelijkheid te scheppen over het rechtskarakter van Europese administratieve soft law-handelingen. In het Verdrag betreffende de Werking van de Europese Unie zou een bepaling kunnen worden opgenomen waarin het rechtskarakter van soft law-handelingen wordt vastgelegd. ${ }^{\mathbf{1 9 8}}$ Aangegeven moet worden onder welke omstandigheden een bindende werking kan bestaan en welke vorm en mate deze bindende werking heeft. Duidelijk moet zijn of het gaat om soft law-handelingen met een sterk bindende werking (afwijking van de soft law-handeling is in principe niet mogelijk) of om soft law-handelingen met een gematigd bindende werking (afwijking is mogelijk, mits gemotiveerd). Ook zou in de Verdragsbepaling kunnen worden gerefereerd aan de hiervoor genoemde procedures. Hoe sterker de bindende werking is, hoe meer betrokkenheid van de lidstaten en het parlement voor de hand ligt. De voorgestelde maatregelen zijn niet alleen wenselijk uit een oogpunt van rechtszekerheid, maar ook uit een oogpunt van transparantie. Een tweede oplossing voor de bestaande rechtsonzekerheid is gelegen in publicatie van de administratieve soft law-handelingen door de Europese Commissie. Daarmee wordt de soft law-handeling toegankelijk voor alle betrokkenen (lidstaten én particulieren).

\section{Bescherming}

Hiervoor is besproken dat de controle van het Hof op de inhoud van soft law-handelingen niet optimaal is omdat deze controle achteraf plaatsvindt en omdat het Hof slechts een selectie van alle soft law-handelingen te zien krijgt. ${ }^{\mathbf{1 9 9}}$ Een aanvullende, meer algemene controle in een eerder stadium is nodig. Deze controlerende taak zou kunnen worden vervuld door de vertegenwoordigers van de lidstaten, die in het hiervoor voorgestelde systeem een zichtbare rol 
gaan spelen bij het vaststellen van de inhoud van de soft law-handelingen. Zij kunnen erop toezien dat de Commissie met de aanname van de soft law-handelingen niet buiten haar bevoegdheidsgrenzen treedt. Voorts zouden ook de nationale rechters een actievere controlerende rol moeten gaan spelen. Daarvoor is het nodig dat het Hof zich openstelt voor geldigheidsvragen ten aanzien van soft law-handelingen.

Ook zou de mogelijkheid om soft law-handelingen rechtstreeks aan te vechten moeten worden uitgebreid. Lidstaten kunnen dan de voor hen vaak bindende handelingen rechtstreeks aanvechten, en bovendien kan dan duidelijkheid worden verkregen over de verenigbaarheid van soft law-handelingen met hoger EU-recht en lidstaten. Het ligt voor de hand dat de weg naar het nietigheidsberoep van artikel 263 VWEU wordt vrijgemaakt.

Tot slot zou de Europese Commissie kunnen stimuleren dat nationale rechters actief worden voorgelicht over de wijze waarop zij zouden moeten omgaan met Europese administratieve soft law-handelingen. Daarmee kan de onduidelijkheid en rechtsonzekerheid die in de rechtspraktijk rondom het rechtskarakter en de status van soft law-handelingen heerst, worden weggenomen. Op het terrein van het staatssteunrecht wordt voorlichting aan nationale rechters, dankzij steun van de Europese Commissie, reeds verzorgd. ${ }^{\mathbf{2 0}} \mathrm{Nu}$ ook in het kader van Europese subsidies meer nadruk komt te liggen op een effectieve uitvoering en handhaving van het Unierecht, ligt het in de rede dat de Commissie deze voorlichting (in ieder geval) ten aanzien van de omgang met soft law op het terrein van de uitvoering van Europese subsidieregelingen (financieel) gaat ondersteunen.

\subsubsection{Tot slot}

In de vorige paragrafen is bezien welke maatregelen kunnen worden genomen op het niveau van de Europese Unie om de spanning tussen het legaliteitsbeginsel en Europese administratieve soft law weg te nemen. Voordat ik een blik werp op het nationale niveau, maak ik nog twee opmerkingen tot slot.

Ten eerste is het mijn bedoeling dat het huidige ondoorzichtige systeem waarin de bindende werking van soft law-handelingen uit verschillende bronnen voortvloeit door het hiervoor geschetste systeem wordt vervangen. De bindende werking van soft law-handelingen vloeit in het nieuwe systeem rechtstreeks voort uit het Verdrag, en wordt met name gelegitimeerd door de (democratische) wijze waarop de soft law-handeling tot stand is gekomen.

De tweede opmerking betreft het voorgestelde systeem gebaseerd op de comitologieprocedures. Het (echte) comitologiesysteem wordt in de literatuur bekritiseerd omdat het systeem het institutionele evenwicht van de Unie zou doorbreken. ${ }^{201}$ De letter en geest van het Werkingsverdrag voorzien volgens critici niet in deze vergaande bemoeienis van de lidstaten. ${ }^{202}$

Geldt deze kritiek ook voor de door mij voorgestelde procedure die voorziet in de betrokkenheid van de lidstaten bij de totstandkoming van soft law? Ik zie hier geen reden toe. ${ }^{\mathbf{2 0 3}}$ In de eerste plaats krijgt het Europese parlement in de nieuwe procedure een belangrijke rol. Dit komt het institutionele evenwicht alleen maar ten goede. Toegegeven, de betrokkenheid van de lidstaten is in het licht van de institutionele balans wellicht niet de meest voor de hand liggende oplossing, maar deze is dit wel in het licht van de relatie tussen de Europese Unie en de lidstaten. Ook deze relatie moet in balans worden gehouden. En juist bij de totstandkoming van administratieve soft law, waarbij de grenzen van de bevoegdheid van de Commissie in beeld komen, is een betrokkenheid van de lidstaten voor deze balans noodzakelijk. Mijns inziens valt deze betrokkenheid bovendien binnen de letter en geest van de EU-Verdragen, in het bijzonder van artikel 5 VEU waarin het attributiebeginsel neergelegd.

\subsection{Oplossingsrichtingen op nationaal niveau}

In de vorige paragraaf zijn oplossingsrichtingen voorgesteld om de beginselen van rechtszekerheid, van legitimiteit en van bescherming tegen de overheid te realiseren, en de knelpunten op nationaal niveau weg te nemen. Zolang de spanning tussen het legaliteitsbeginsel en Europese administratieve soft law niet bij de bron, op Europees niveau, wordt weggenomen, blijven de knelpunten op nationaal niveau bestaan. In deze laatste paragraaf bezie ik welke maatregelen 'for the time being' op nationaal niveau kunnen worden 
genomen om de symptomen (zoveel mogelijk) te bestrijden.

Allereerst is het van belang dat het bestuur niet klakkeloos de soft law-handelingen van de Commissie volgt. De meeste soft law-handelingen geven de ruimte om een concreet geval te beoordelen en een individuele afweging te maken. Dit betekent dat als er reden is om van een soft law-handeling af te wijken, het bestuur dit ook, gemotiveerd, moet doen. Met andere woorden, het bestuur zou niet altijd de veilige weg moeten kiezen. Door de eigen bewegingsruimte zoveel mogelijk te blijven benutten, beschermt het bestuur zichzelf tegen de uitdijende macht van de Europese Unie. Gelukkig, zo kwam naar voren in de derde paragraaf, ziet het CBB er (niet altijd op goede gronden) op toe dat het bestuur, waar mogelijk, een eigen afweging blijft maken.

Ten tweede is het van belang dat Nederlandse vertegenwoordigers in Brussel zoveel mogelijk betrokken zijn bij de totstandkoming van soft law-handelingen. De vertegenwoordigers zouden bij de onderhandelingen aan kunnen geven hoe 'Nederland' tegenover een specifieke soft lawhandeling staat: of het de handeling aanvaardt of niet. Dit voorkomt dat Nederland onbedoeld aan een soft law-handeling wordt gebonden doordat aanvaarding wordt aangenomen. De vertegenwoordigers zouden bovendien hun collega's in Den Haag moeten informeren hoe hun betrokkenheid bij de totstandkoming er uit heeft gezien, en zo mogelijk ook welke procedure is gevolgd. Ook met deze betrokkenheid en rapportage (die zorgt voor transparantie) kan het legitimiteitsbegrek dat aan soft law-handelingen kleeft, enigszins worden gerepareerd. Ten derde dient er op nationaal niveau voor te worden gezorgd dat soft law-handelingen voor de betrokkenen kenbaar zijn. De handelingen zouden bijvoorbeeld in beleidsregels of wetgeving kunnen worden neergelegd. Mijn voorkeur gaat uit naar het neerleggen van soft law in beleidsregels, omdat dan voor het bestuur een afwijkingsmogelijkheid blijft bestaan. Daarnaast zouden burgers die daarbij belang hebben op de hoogte moeten worden gesteld van de inhoud van voor hen relevante soft law-handelingen. De in de tweede paragraaf besproken 'vijftig bomen-casus' is een goed voorbeeld. De subsidieaanvrager zou voordat hij zijn aanvraag definitief indient van het vijftig-bomen criterium op de hoogte moeten worden gesteld. Rechtszekerheid wordt zo op een meer directe manier gerealiseerd dan als de soft lawhandelingen (alleen) in beleidsregels worden neergelegd. ${ }^{\mathbf{2 0 4}}$

Ten vierde heeft de rechter in Nederland een belangrijke taak. Gebleken is dat het CBB vaak de weg van niet-verbindendheid kiest. Dit is begrijpelijk omdat de jurisprudentie van het Hof niet uitblinkt in duidelijkheid en omdat de Nederlandse rechter op de Nederlandse legaliteitsleer is georiënteerd. Toch zou het CBB mijns inziens niet zijn ogen moeten sluiten voor de ondoorzichtige jurisprudentie van het Hof en meer onderzoek moeten verrichten naar de mogelijke bindende werking van soft law-handelingen. Bijvoorbeeld zou vaker een prejudiciële vraag kunnen worden gesteld over het karakter van een soft law-handeling. Hierdoor wordt op nationaal niveau niet alleen meer duidelijkheid verschaft, ook wordt het Hof van Justitie (hoop ik) gestimuleerd om minder terughoudend te zijn in het beantwoorden van geldigheidsvragen.

Om het CBB en andere nationale rechters meer bekend te maken met de jurisprudentie van het Hof inzake (de bindende werking van) soft law en de rechters te stimuleren om prejudiciële vragen te stellen, zouden op nationaal niveau projecten kunnen worden opgezet om de nationale rechters hierover actief voor te lichten. Deze initiatieven zullen de Commissie er wellicht toe aanzetten om dergelijke initiatieven te stimuleren en te ondersteunen. Zo wordt met een nationale maatregel een voorzet gegeven voor actie op Europees niveau

\subsection{Conclusie}

De voor de handliggende oplossing om de spanning met het legaliteitsbeginsel weg te nemen is om soft law om te zetten in hard law. Door deze transformatie gaat het flexibele karakter van soft law echter verloren. Ook het ontnemen van iedere bindende werking aan soft lawhandelingen is geen geschikte oplossing, omdat het goed functioneren van de Unie dan in gevaar komt. Er moeten dus maatregelen worden genomen waarmee administratieve soft law een bindende werking kan blijven genereren.

Om rechtszekerheid te creëren zou (de totstandkoming) van soft law-handelingen een juridische basis moeten krijgen in de Verdragen en zouden soft law-handeligen moeten worden gepubliceerd. Uit een oogpunt van legitimiteit is betrokkenheid van het Europese Parlement en 
van de lidstaten bij de totstandkoming van soft law een oplossing, net als het creëren van een transparante besluitvormingsprocedure en een openbaar debat. De lidstatelijke controle en een uitbreiding van de rechtsbeschermingsmogelijkheden zorgen ervoor dat aan het beschermingsbeginsel voldaan.

Deze maatregelen op het niveau van de Europese Unie zorgen ervoor dat de knelpunten bij de doorwerking van Europese administratieve soft law in de Nederlandse rechtsorde grotendeels worden weggenomen. Vooralsnog zijn deze maatregelen echter geen realiteit. Daarom moet ook op nationaal niveau actie worden ondernomen om zoveel mogelijk in rechtszekerheid, in legitimiteit en in bescherming tegen de Unie te voorzien. Dit betekent onder meer dat Nederland bij de totstandkoming van soft law betrokkenheid moet tonen, dat meer prejudiciële vragen moeten worden gesteld, dat burgers van de inhoud van voor hen belangrijke soft lawhandelingen op de hoogte moeten worden gesteld en dat soft law-handelingen in beleidsregels of zelfs in wetgeving moeten worden neergelegd.

\section{Legitimiteit}

Hiervoor is besproken dat met name van de totstandkoming van Europese administratieve soft een gering legitimerend effect uitgaat. Europese administratieve soft law zou meer input- en througput-legitimiteit moeten genereren. Input-legitimiteit kan in de eerste plaats worden gegenereerd door het Europese Parlement te betrekken bij de totstandkoming van administratieve soft law. De Commissie zou een ontwerp soft law-handeling ter consultatie kunnen voorleggen aan het Europese parlement. Hiervoor heeft overigens ook het Europese parlement zelf gepleit in zijn resolutie over de institutionele en juridische gevolgen van het gebruik van "soft-law" instrumenten. ${ }^{\mathbf{2 0 5}}$

In de tweede plaats zouden ook (vertegenwoordigers van) de lidstaten bij de totstandkoming van Europese administratieve soft law kunnen worden ingeschakeld. Betrokkenheid van de lidstaten heeft immers een sterk legitimerend effect. Daarbij maakt deze betrokkenheid het mogelijk dat de lidstaten ervoor kunnen waken dat de Commissie niet buiten haar bevoegdheden treedt. ${ }^{206}$ De betrokkenheid van de lidstaten is dus ook van belang in het licht van het beschermingsbeginsel.

Ik stel voor dat het ontwerp van de Commissie, voordat het naar het Europese parlement wordt gestuurd, wordt voorgelegd aan vertegenwoordigers van de lidstaten. Gedacht kan worden aan een soortgelijk systeem als het systeem van 'comitologie', waarin comités, bestaande uit lidstatelijke vertegenwoordigers, de Commissie ondersteunen bij het vaststellen van uitvoeringsregels. ${ }^{207}$ Deze ondersteuning heeft een vergaand karakter: de comités kunnen zelfs de inhoud van de regelingen bepalen en de totstandkoming van de regelingen dwarsbomen. ${ }^{\mathbf{2 0 8}}$ Lidstatelijke vertegenwoordigers, verenigd in comités, zouden in vergelijkbare zin een bijdrage kunnen leveren aan de totstandkoming van soft law-handelingen. ${ }^{209}$ Welke rol deze comités precies moeten spelen, moet nader worden uitgedacht. Ik denk aan een procedure waarin de comités niet alleen een adviserende rol hebben, maar waarin zij ook wijzigingen kunnen aanbrengen in het voorstel van de Commissie. Als het gaat om soft law-handelingen die een sterk bindende werking hebben, zouden de lidstaten zelfs de mogelijkheid moeten krijgen om een niet-aanvaardbaar uit te spreken over de definitieve versie. ${ }^{\mathbf{2 1 0}}$ Dit betekent dat de soft lawhandeling voor die lidstaat geen bindende werking heeft. ${ }^{\mathbf{2 1 1}}$

Voor soft law-handelingen waar een gematigd bindende werking van uitgaat, bijvoorbeeld handelingen ten aanzien waarvan is bepaald dat zij 'in aanmerking moeten worden genomen', is een veto niet nodig omdat inherent aan deze vorm van bindende werking is dat de lidstaten gemotiveerd kunnen afwijken.

In de derde plaats dient de hierboven beschreven procedure transparant te zijn. Ook transparantie genereert immers throughput-legitimiteit. ${ }^{\mathbf{2 1 2}}$ Dit betekent dat naar buiten toe duidelijkheid moet worden geschapen over de verschillende stappen in de procedure, maar ook over de rol die de verschillende actoren (de Commissie, het Parlement, en de comités) in de procedure spelen. ${ }^{\mathbf{2 1 3}}$ Ook dient het debat waarin over de inhoud van de soft law-handelingen wordt onderhandeld zoveel mogelijk openbaar te zijn. Vooral ten aanzien van het debat in de comités zal verder moeten worden nagedacht over de vraag hoe deze openbaarheid te realiseren. Gedacht kan worden aan de mogelijkheid dat een verslag van het debat in de Comités naar het Europese Parlement en de nationale parlementen wordt gestuurd. 


\section{Rechtszekerheid}

Rechtszekerheid kan in de eerste plaats worden gecreëerd door duidelijkheid te scheppen over het rechtskarakter van Europese administratieve soft law-handelingen. In het Verdrag betreffende de Werking van de Europese Unie zou een bepaling kunnen worden opgenomen waarin het rechtskarakter van soft law-handelingen wordt vastgelegd. ${ }^{\mathbf{2 1 4}}$ Aangegeven moet worden onder welke omstandigheden een bindende werking kan bestaan en welke vorm en mate deze bindende werking heeft. Duidelijk moet zijn of het gaat om soft law-handelingen met een sterk bindende werking (afwijking van de soft law-handeling is in principe niet mogelijk) of om soft law-handelingen met een gematigd bindende werking (afwijking is mogelijk, mits gemotiveerd). Ook zou in de Verdragsbepaling kunnen worden gerefereerd aan de hiervoor genoemde procedures. Hoe sterker de bindende werking is, hoe meer betrokkenheid van de lidstaten en het parlement voor de hand ligt. De voorgestelde maatregelen zijn niet alleen wenselijk uit een oogpunt van rechtszekerheid, maar ook uit een oogpunt van transparantie. Een tweede oplossing voor de bestaande rechtsonzekerheid is gelegen in publicatie van de administratieve soft law-handelingen door de Europese Commissie. Daarmee wordt de soft law-handeling toegankelijk voor alle betrokkenen (lidstaten én particulieren).

\section{Bescherming}

Hiervoor is besproken dat de controle van het Hof op de inhoud van soft law-handelingen niet optimaal is omdat deze controle achteraf plaatsvindt en omdat het Hof slechts een selectie van alle soft law-handelingen te zien krijgt. ${ }^{\mathbf{2 1 5}}$ Een aanvullende, meer algemene controle in een eerder stadium is nodig. Deze controlerende taak zou kunnen worden vervuld door de vertegenwoordigers van de lidstaten, die in het hiervoor voorgestelde systeem een zichtbare rol gaan spelen bij het vaststellen van de inhoud van de soft law-handelingen. Zij kunnen erop toezien dat de Commissie met de aanname van de soft law-handelingen niet buiten haar bevoegdheidsgrenzen treedt. Voorts zouden ook de nationale rechters een actievere controlerende rol moeten gaan spelen. Daarvoor is het nodig dat het Hof zich openstelt voor geldigheidsvragen ten aanzien van soft law-handelingen.

Ook zou de mogelijkheid om soft law-handelingen rechtstreeks aan te vechten moeten worden uitgebreid. Lidstaten kunnen dan de voor hen vaak bindende handelingen rechtstreeks aanvechten, en bovendien kan dan duidelijkheid worden verkregen over de verenigbaarheid van soft law-handelingen met hoger EU-recht en lidstaten. Het ligt voor de hand dat de weg naar het nietigheidsberoep van artikel 263 VWEU wordt vrijgemaakt.

Tot slot zou de Europese Commissie kunnen stimuleren dat nationale rechters actief worden voorgelicht over de wijze waarop zij zouden moeten omgaan met Europese administratieve soft law-handelingen. Daarmee kan de onduidelijkheid en rechtsonzekerheid die in de rechtspraktijk rondom het rechtskarakter en de status van soft law-handelingen heerst, worden weggenomen. Op het terrein van het staatssteunrecht wordt voorlichting aan nationale rechters, dankzij steun van de Europese Commissie, reeds verzorgd. ${ }^{\mathbf{2 1 6}} \mathrm{Nu}$ ook in het kader van Europese subsidies meer nadruk komt te liggen op een effectieve uitvoering en handhaving van het Unierecht, ligt het in de rede dat de Commissie deze voorlichting (in ieder geval) ten aanzien van de omgang met soft law op het terrein van de uitvoering van Europese subsidieregelingen (financieel) gaat ondersteunen.

\section{Conclusie}

Onderzocht is op welke wijze Europese administratieve soft law doorwerkt in de Nederlandse rechtsorde, en in hoeverre deze doorwerking een probleem vormt in het licht van het legaliteitsbeginsel. Het onderzoek is uitgevoerd op het terrein van de uitvoering van Europese subsidieregelingen.

Europese administratieve soft law heeft geen uitdrukkelijke juridische basis in de Verdragen en mist juridische verbindendheid als inherente eigenschap. Toch gaat van administratieve soft law-handelingen in mindere of meerdere mate een bindende werking uit naar de lidstaten. Deze bindende werking kan voortvloeien uit een onderliggende hard law- bepaling (op grond van een samenwerkingsplicht en aanvaarding of op grond van een specifieke rechtsgrondslag in 
secundaire hard law). Ook als een bindende werking niet voortvloeit uit een onderliggende hard law-bepaling, zorgen de Grimaldi-rechtspraak en de comply or explain-praktijk van de Commissie voor een gematigd bindende werking. Een feitelijk bindende werking kan tot slot voortvloeien uit een afhankelijkheidsrelatie tussen de lidstaten en de Commissie. Dit is het geval op het terrein van de Europese subsidies, zo volgt uit het bottom-up onderzoek dat is verricht in dit artikel. Verder onderzoek zou moeten worden verricht naar de mate van feitelijk bindende werking van soft law-handelingen die worden vastgesteld op andere beleidsterreinen waarop geen of een minder evidente afhankelijkheidsrelatie tussen de lidstaten en de Commissie bestaat.

Aan de drie beginselen die het legaliteitsbeginsel dient (het bieden van bescherming tegen de overheid (in dit geval de Europese Unie), het genereren van legitimiteit en het bevorderen van rechtszekerheid), wordt met de doorwerking van Europese administratieve soft law in veel opzichten niet voldaan. Vanwege het bindende effect van soft law-handelingen, wordt de ruimte die de lidstaten hebben om het Unierecht toe te passen sluipenderwijs door de Commissie ingevuld. De totstandkoming van administratieve soft law heeft een gering legitimerend effect. Rechtsonzekerheid ontstaat doordat administratieve soft law-handelingen vaak niet worden gepubliceerd en doordat onduidelijkheid bestaat over het rechtskarakter van soft law-handelingen.

Verschillende oplossingsrichtingen zijn voorgesteld om de legaliteitsproblemen die in dit onderzoek zijn geconstateerd op te lossen. Het Europese parlement en de lidstaten zouden bij de totstandkoming van administratieve soft law moeten worden betrokken om legitimiteit te creëren. Rechtszekerheid kan worden bevorderd door in een Verdragsbepaling duidelijkheid te scheppen over het rechtskarakter van soft law-handelingen en over de totstandkomingsprocedure. Ook op nationaal niveau moet actie worden ondernomen. Van belang is met name dat de nationale rechter (meer) prejudiciële vragen stelt over de bindende werking van soft law-handelingen en dat nationale vertegenwoordigers actief betrokken zijn bij de totstandkoming van soft law-handelingen in Brussel. Voorts zouden soft law-handelingen in beleidsregels kunnen worden neergelegd of zouden betrokkenen van de inhoud van (voor hen relevante) soft law-handelingen op de hoogte kunnen worden gesteld.

\section{Literatuurlijst}

Adriaanse 2008

P.C. Adriaanse, 'Afzien van terugvordering van in strijd met het gemeenschapsrecht verleende financiële steun vanwege het rechtszekerheidsbeginsel?, NTER 2008, p. 40-46.

\section{Adriaanse en Den Ouden 2008}

P.C. Adriaanse en W. den Ouden, 'Effectuering van staatssteunrecht in Nederland. Een bestuursrechtelijke blik op de uitvoeringspraktijk en het wetsvoorstel terugvordering staatssteun', NTB 2008, p. 304-315.

Ambtenbrink en Vedder 2010

F. Ambtenbrink en H.H.B. Vedder, Recht van de Europese Unie, Den Haag: Boom Juridische Uitgevers, 2010.

Blumann en Dubouis 2010 C. Blumann en L. Dubouis, Droit institutionnel de l'Union européenne, Parijs: Lexis Nexis 2010.

De Burca 2011

G. de Búrca, 'The quest for legitimacy in the European Union, The Modern Law Review, 2011, p. $349-376$.

Van den Brink 2010

J.E. van den Brink, 'Europese grenzen aan het rechtszekerheids- en vertrouwensbeginsel', in: M.J.M. Verhoeven, J.E. van den Brink en A. Drahmann (Eds.) Europees offensief tegen nationale beginselen? Over legaliteit, rechtszekerheid, vertrouwen en transparantie Vol. 8. 
Preadviezen Jonge VAR-reeks. Den Haag: Boom Juridische uitgevers, 2010 p. 63-141.

Collignon 2006

S. Collignon, 'Democracy and Europe's crisis of legitimacy', Intervention: European Journal of Economics and Economic Policies', 2006, p. 75-85.

Damen 1987

L.J.A. Damen, Ongeregeld en ondoorzichtig bestuur, Deventer: Kluwer.

Dammers 2007

W.F. Dammers, Comitology in the decision-making process of the European Union: Good Governance Guaranteed?, Nijmegen: Wolf Legal Publishers 2007.

Eijsbouts e.a. 2010

W.T. Eijsbouts, J.H. Jans, A. Prechal en L.A.J. Senden, Europees recht. Algemeen deel, Groningen: Europa Law Publishing 2010.

De Haan, Drupsteen en Fernhout 2001

P. de Haan, Th. G. Drupsteen, R. Fernhout, Bestuursrecht in de sociale rechtsstaat. Deel 1: Ontwikkeling, organisatie, instrumentarium, Deventer: Kluwer 2001.

Jans, Prechal en Widdershoven 2010

J.H. Jans, S. Prechal, R.J.G.M. Widdershoven, Inleiding tot het Europees bestuursrecht, Nijmegen: Ars Aequi Libri 2010.

De Koninck 1992

C. de Koninck, 6oo Latijnse Rechtsspreuken, Gent: Mys \& Breesch 1992.

Kortmann 2008

C.A.J.M. Kortmann, Constitutioneel Recht, Deventer: Kluwer 2008

Den Ouden 2009

W. Den Ouden, Bug-Alutechnik. De Europese invloed op het vertrouwensbeginsel bij terugvorderingszaken', in T. Barkhuysen, J.E.M. Polak, B.J. Schueler en R.J.G.M. Widdershoven, $A B$ Klassiek, Deventer: Kluwer 2009, p. 253-262.

Den Ouden, Jacobs en Verheij 2011

W. Den Ouden, M.J. Jacobs, N. Verheij, Subsidierecht, Deventer: Kluwer 2011.

Van Kreveld 1983

J.H. van Kreveld, Beleidsregels in het recht, Deventer: Kluwer 1983.

Lefevre 2004

S. Lefevre, Interpretative Communications and the implementation of Community law at national level', European Law Review 2004, p. 808-822.

Klap en Olivier

A.P. Klap en B.K. Olivier, 'Beleidsregels', NJB 1998, p. 772-779.

Lauwaars 1993

R.H. Lauwaars, 'Zijn er beleidsregels in Europa?', NTB 1993, p. 18-25.

Luijendijk en Senden

H. Luijendijk en L.A.J. Senden, 'De gelaagde doorwerking van Europese administratieve soft law in de nationale rechtsorde', $S E W$ 2011, p. 312-352.

Parkinson 2003 
J. Parkinson, 'Legitimacy problems in deliberative democracy', Political Studies, 2003, p. 180-196.

Mortelmans 1979

K.J.M. Mortelmans, 'De rechtsbescherming bij pseudo-wetgeving in het Europees economisch recht', SEW 1979, p. 16-30.

Oldenziel 1998

H.A. Oldenziel, Wetgeving en rechtszekerheid: een onderzoek naar de bijdrage van het legaliteitsvereiste aan de rechtszekerheid van de burger, Deventer: Kluwer 1998.

Van Ommeren 1996

F.J. van Ommeren, De verplichting verankerd. De reikwijdte van het legaliteitsbeginsel en het materiële wetsbegrip, Deventer: W.E.J. Tjeenk Willink 1996.

Scharpf 1999.

F.W. Scharpf, Governing in Europe: Effective and Democratic?, Oxford: Oxford University Press 1999.

Scharpf 2009

F. W. Scharpf, 'Legitimacy in the multilevel European polity', European Political Sciences Review, 2009, p. 173-204

Scheltema 1996

Scheltema, 'Van rechtsbescherming naar een volwaardig bestuursrecht', NJB 1996, p. 13551361.

Scheltema 2011

M. Scheltema, 'Legaliteit als middel tot een doel', NJB 2011, p. 1432-1436.

Schöndorf-Haubold 2005

B. Schöndorf-Haubold, 'Die Strukturfonds der Europäischen Gemeinschaft. Rechtsformen und Verfahren europäischer Verbundverwaltung, München: Verlag C.H. Beck 2005.

Schmidt 2010

V. Schmidt, 'Democracy and Legitimacy in the European Union Revisited, Political Studies 2012, Political Studies, gepubliceerd online op 7 augustus 2012, zie

http://onlinelibrary.wiley.com/doi/10.1111/j.1467-9248.2012.0o962.x/abstract.

Scott 2011

J. Scott, 'In Legal limbo: post-legislative guidance as a challenge for European administrative law', CMLRev 2011, p. 329-355.

Senden 1996

L.A.J. Senden, 'De toevlucht tot soft law door de Europese Commissie', RegelMaat 1997, p. 228-239.

Senden 2004

L.A.J. Senden, Soft law in European Community Law, Oxford: Hart Legal Publishing 2004.

Senden en Tahtah

L.A.J. Senden \& A. Tahtah, 'Reguleringsintensiteit en regelgevingsinstrumentarium in het Europees Gemeenschapsrecht. Over de relatie tussen wetgeving, soft law en de open methode van coördinatie', $S E W 2008$ p. 43-57.

Stefan 2012

O. Stefan, 'Hybridity before the court a hard look at soft law in the EU competition and state 
aid case law', European Law Review 2012, p. 49-69.

Verhey 1989

N. Verheij, 'Alleen de wet heerscht over ons', Publiek Domein 1989, p. 188-197.

Verhoeven en Widdershoven 2011.

M. Verhoeven en R. Widdershoven, 'National Legality and European Obligations' in: L. Besselink, F. Pennings en S. Prechal (red.), The Eclipse of the Legality Principle in the European Union, Kluwer International 2011

Verhoeven 2011

M. Verhoeven, The Costanzo Obligation. The obligations of National Administrative Authorities in the Case of Incompatibility between National Law and European Law, Antwerpen: Intersentia 2011.

Van der Vlies 1984.

I.C. van der Vlies, Het wetsbegrip en beginselen van behoorlijke regelgeving, diss. Uva 1984.

Voermans 1998

W.J.M. Voermans, 'Beleidsregels', in B.M.J. van der Meulen (eds.), Info derde tranche Algemene wet bestuursrecht, Den Haag: Vuga 1998 p. 45-80.

Voermans 2008

W. Voermans, 'Is de Europese wetgever na Lissabon wel een échte wetgever?', in: R.A.J. van Gestel, J. van Schooten (eds.), Europa en de toekomst van de nationale wetgever, Nijmegen: Wolf Legal Publishers 2008.

Voermans 2011

W.J.M. Voermans, Legaliteit als middel tot een doel. Controverses rondom legaliteit en legitimatie; handelingen NJV 141e jaargang. Handelingen Nederlandse Juristen Vereniging, Deventer: Kluwer 2011.

Westra en Den Ouden 2001

K.M. Westra en W. Den Ouden, Algemeen bestuursrecht 20o1: subsidies, Den Haag: Boom Juridische Uitgevers, 2001.

Widdershoven 2009

Zie R.J.G.M Widdershoven, 'Kraaijeveld. Doorwerking van EG-recht in de nationale rechtsorde', in T. Barkhuysen, J.E.M. Polak, B.J. Schueler en R.J.G.M. Widdershoven, $A B$ Klassiek, Deventer: Kluwer 2009, 427-440.

Van Wijk/Konijnenbelt en Van Male 2011 H.D. Van Wijk (bewerkt door W. Konijnenbelt en R. van Male), Hoofdstukken van Bestuursrecht, Amsterdam: Reed Business 2011.

\section{Noten}

1 De Koninck 1992, p. 28.

2 Verheij 1989, p. 188 e.v.

3 Verhoeven 2011, p. 163.

4 Voermans 1998, p. 45, 46.

5 Van Wijk/Konijnenbelt 2011, 219. 
6 Guidelines for Community Noise, 1999 (te vinden via

http://whqlibdoc.who.int/hq/1999/a68672.pdf) en het Fact Sheet nr. 258, on Occupational and Community Noise, herzien in februari 2001, (te vinden via

http://www.who.int/peh/Occupational_health/OCHweb/OSHpages/OSHDocuments/Factsheets/noise.pdf).

7 Luijendijk en Senden 2011, p. 316.

8 Het Europese parlement gebruikt de termen mollis lex (letterlijk: zacht recht) en dura lex. Zie de Resolutie van het Europees Parlement van 4 september 2007 over de institutionele en juridische gevolgen van het gebruik van 'soft-law' instrumenten, A6-0259/2007, p. 3 .

9 Luijendijk en Senden 2011, p. 313 en 318.

10 Senden 1997, p. 234.

11 Senden en Tahtah 2008, p. 48.

12 Ten aanzien van primair en secundair unierecht vindt doorwerking hoofdzakelijk plaats via rechtstreekse werking en richtlijnconforme interpretatie (zie bijvoorbeeld Jans, Prechal en Widdershoven 2010, p. 57). Omdat administratieve soft law niet tot het primaire en secundaire unierecht behoort, is het nodig om meer in het algemeen de omgang met Europese

administratieve soft law te onderzoeken om de juridische effecten te kunnen duiden.

13 Senden 2004, p. 112.

14 Luijendijk en Senden 2011, p. 316.

15 Senden en Tahtah 2008, p 47.

16 Luijendijk en Senden 2011, p. 317. Volgens Scott geeft Europese administratieve soft law 'post-legislative guidance'. Zie Scott 2011 p. 329.

17 Zie bijvoorbeeld COM (2001)351, Mededeling van de Commissie van 27 juni 2001 over de toepassing van de algemene beginselen van het vrije verkeer van goederen en diensten - artikel 28 en 49 van het Verdrag - op het gebied van het gebruik van schotelantennes. COM(2001)351 def.

18 Zie artikel 19 lid 1 VEU.

19 Luijendijk en Senden 2011, p. 316. Zie bijvoorbeeld de 'Richtsnoeren inzake regionale steunmaatregelen' van de Europese Commissie van 10 maart 1998 ( $P b E G$ 1998, C 74/o6).

20 Luijendijk en Senden 2011, p. 317.

21 Deze vorm is onder meer te vinden op het gebied van Europese subsidies, zie bijvoorbeeld het Oriëntatiedocument AGRI/60363/2005-REV1 van de Europese Commissie inzake de controles ter plaatse van de oppervlakte van de meting van de oppervlakte overeenkomstig de artikelen 23 tot en met 32 van Verordening 796/2004 van de Europese Commissie.

22 Uitzondering zijn de aanbevelingen en de adviezen, genoemd in artikel 288 VWEU ten aanzien waarvan is bepaald dat zij niet verbindend zijn.

23 Lefevre 2004, p. 821. Hij noemt als voorbeeld het ontwerp van de interpretatieve mededeling van de Commissie, Vrij verrichten van diensten en algemeen belang in het verzekeringsbedrijf, SEC(1997)1824.

24 Dit is een ruime interpretatie van het begrip implementatie (vgl. Voermans 2011, p. 178). 
Vaak wordt onder implementatie alleen de omzetting van richtlijnen verstaan (Zie bijvoorbeeld Jans, Prechal, en Widdershoven 2011, p. 10). Een verplichting tot omzetting van Europese administratieve soft law bestaat echter niet. Om de effecten van Europese administratieve soft law in kaart te kunnen brengen, kan met deze strikte interpretatie derhalve niet worden volstaan.

25 Vgl. Den Ouden, Jacobs en Verheij 2011, p. 222.

26 Eijsbouts e.a. 2010, p. 28.

27 Jans, Prechal en Widdershoven 2010 p. 26, 27.

28 Luijendijk en Senden 2011, p. 318.

29 Senden en Tahtah 2008, p. 48.

30 In de literatuur wordt in dit verband wel gesproken van incidentele of feitelijke juridische verbindendheid (zie bijvoorbeeld Senden \& Tahtah 2008, p. 48). Omdat administratieve soft law op grond van de Verdragen niet juridisch verbindend is, houd ik vast aan de term 'bindende werking' (die ook door het Hof wordt gebruikt). Deze juridisch bindende werking moet worden onderscheiden van de hierna te bespreken de facto bindende werking (zie par. 2.2.2.4. en par. 3.4.).

31 HvJ EG 31 maart 1971, zaak 22/70, Jur. 1971, p. 263, r.o. 42 (ERTA).

32 Bijv. HvJ EG 16 juni 1993, zaak C-325/91, Jur. 1993, p. I-3283, r.o. 9 (Frankrijk/Commissie).

33 Senden en Tahtah 2008, p. 48.

34 HvJ EG 15 juni 1994, zaak C-137/92, 1994, Jur. 1994 p. I-2555, r.o. 48 (Commissie/BASF). Alleen als aan een handeling een onregelmatigheid van een zo klaarblijkelijke ernst kleeft dat zij door de unierechtelijke rechtsorde niet kan worden getolereerd, moet zij als juridisch nonexistent worden beschouwd (de handeling wordt dan geacht geen enkel rechtsgevolg in het leven te hebben geroepen). Hiervan is volgens het Hof zelden sprake. Zie r.o. 49 van voorgenoemd arrest.

35 Vgl. Luijendijk \& Senden 2011, p. 318.

36 HvJ EG 20 maart 1997, zaak C-57/95, Jur. 1997, p. I-1640, r.o. 21 (Frankrijk/Commissie). Zie daarover ook Senden 2004, p. 254, 255.

37 Dit wordt ook wel een 'rechtsgrondslag' genoemd.

38 HvJ EG 15 oktober 1996, zaak C-311/94, Jur.1996, p. I-5023, r.o. 43 (IJssel-Vliet).

39 HvJ EG 5 oktober 2000, zaak C-288/96, Jur. 2000, p. I-8237, r.o. 65 (Commissie/Duitsland).

40 Zie haar noot bij CBB 27 oktober 2010, $A B$ 2011, 173, punt 4.

41 Adriaanse en Den Ouden 2008, p. 305.

42 Richtsnoeren voor deze samenwerking zijn neergelegd in de Bekendmaking van de Commissie betreffende samenwerking tussen nationale en rechterlijke instanties en de Commissie op het gebied van steunmaatregelen van de Staten van 23 november 1995, (PbEG 1995, C-312/8); Zie ook Adriaanse en Den Ouden 2008, p. 305. 
43 Artikel 108 lid 1 VWEU.

44 Het uitgangspunt dat naleving van Europese administratieve soft law op vrijwillige basis geschiedt, is bevestigd in de Nefarma-uitspraak (GvEA EG 13 december 1990, zaak T-113/89, Jur. 1990, p. II-797I).

45 Zie voor een voorbeeld CBB 30 augustus 2011, $A B$ 2012, 96 m.nt. W. Den Ouden.

46 Richtlijn 2002/21/EG van het Europees Parlement en de Raad van 7 maart 2002 inzake een gemeenschappelijk regelgevingskader voor elektronische communicatienetwerken en diensten, (PbEG 2002, L 108/33).

47 Luijendijk en Senden 2011, p. 331.

48 HvJ EG 11 mei 2006, zaak C-11/o5, Jur. 2006, p. I-4285, (Friesland Coberco Dairy Foods/Inspecteur van de Belastingdienst).

49 Zie J.E. van den Brink in haar noot bij CBB 27 oktober 2010, $A B$ 2011, 173, punt 6.

50 HvJ EU 15 oktober 1996, zaak C-311/94, Jur 1996, p. I-5023, r.o. 44 (IJssel-Vliet).

$\mathbf{5 1}$ Het gaat om de Richtsnoeren voor het onderzoek van de nationale steunmaatregelen in de visserijsector, (PbEG 1988, C 313/21).

52 HvJ EG 11 mei 2006, zaak C-11/o5, Jur. 2006, p. I-4285, r.o. 26 en 27 (Friesland Coberco Dairy Foods/Inspecteur van de Belastingdienst).

53 HvJ EG 13 december 1989, zaak C-322/88, Jur. 1989, p. I-4407, r.o. 16 (Grimaldi).

54 HvJ EG 13 december 1989, zaak C-322/88, Jur. 1989, p. I-4407, r.o. 18 (Grimaldi).

55 Vgl. Senden 2004, p. 387-391; Luijendijk en Senden 2011, p. $336 .$.

56 Zie bijvoorbeeld Luijendijk en Senden 2011, p. 336 waar zij de Grimaldi-formule op 'echte' soft law-handelingen van toepassing achten; Zie ook Stefan 2012, p. 60.

57 Zie hiervoor paragraaf 2.2.1.

58 Vgl. Luijendijk en Senden 2011, p. 334.

59 HvJ EG 16 juni 2005, zaak C-105/o3, Jur. 2005, p. I-5285 (Pupino); Zie ook Jans, Prechal en Widdershoven. 2011, p. 64 en 65.

6o Vgl. In dit kader de uitspraak Stichting Rom-projecten waarin het Hof overweegt dat een Commissiebeschikking die niet is bekendgemaakt en die verplichtingen bevat voor een burger, niet aan de burger mag worden tegengeworpen, zie HvJ EG 21 juni 2007, zaak C-158/o6, $A B$ 2007, 239 m.nt. Griffioen en W. den Ouden. Zie daarover Den Ouden 2009, p. 260.

61 Het uitgangspunt dat naleving van Europese administratieve soft law op vrijwillige basis geschiedt, is bevestigd in de Nefarma-uitspraak (GvEA EG 13 december 1990, zaak T-113/89, Jur. 1990, p. II-797I).

62 Zie voor een voorbeeld CBB 30 augustus 2011, $A B$ 2012, 96 m.nt. W. Den Ouden.

63 Richtlijn 2002/21/EG van het Europees Parlement en de Raad van 7 maart 2002 inzake een gemeenschappelijk regelgevingskader voor elektronische communicatienetwerken en diensten, (PbEG 2002, L 108/33). 
64 Luijendijk en Senden 2011, p. 331.

65 HvJ EG 11 mei 2006, zaak C-11/o5, Jur. 2006, p. I-4285, (Friesland Coberco Dairy Foods/Inspecteur van de Belastingdienst).

66 Zie J.E. van den Brink in haar noot bij CBB 27 oktober 2010, $A B$ 2011, 173, punt 6.

67 HvJ EU 15 oktober 1996, zaak C-311/94, Jur 1996, p. I-5023, r.o. 44 (IJssel-Vliet).

68 Het gaat om de Richtsnoeren voor het onderzoek van de nationale steunmaatregelen in de visserijsector, (PbEG 1988, C 313/21).

69 HvJ EG 11 mei 2006, zaak C-11/o5, Jur. 2006, p. I-4285, r.o. 26 en 27 (Friesland Coberco Dairy Foods/Inspecteur van de Belastingdienst).

70 HvJ EG 13 december 1989, zaak C-322/88, Jur. 1989, p. I-4407, r.o. 16 (Grimaldi).

71 HvJ EG 13 december 1989, zaak C-322/88, Jur. 1989, p. I-4407, r.o. 18 (Grimaldi).

72 Vgl. Senden 2004, p. 387-391; Luijendijk en Senden 2011, p. 336..

73 Zie bijvoorbeeld Luijendijk en Senden 2011, p. 336 waar zij de Grimaldi-formule op 'echte' soft law-handelingen van toepassing achten; Zie ook Stefan 2012, p. 60.

74 Zie hiervoor paragraaf 2.2.1.

75 Vgl. Luijendijk en Senden 2011, p. 334.

76 HvJ EG 16 juni 2005, zaak C-105/o3, Jur. 2005, p. I-5285 (Pupino); Zie ook Jans, Prechal en Widdershoven. 2011, p. 64 en 65.

77 Vgl. In dit kader de uitspraak Stichting Rom-projecten waarin het Hof overweegt dat een Commissiebeschikking die niet is bekendgemaakt en die verplichtingen bevat voor een burger, niet aan de burger mag worden tegengeworpen, zie HvJ EG 21 juni 2007, zaak C-158/o6, $A B$ 2007, 239 m.nt. Griffioen en W. den Ouden. Zie daarover Den Ouden 2009, p. 260.

$\mathbf{7 8}$ In veel gevallen is sprake van co-financiering. De lidstaat neemt dan een deel (meestal 50\% of meer) van de kosten voor zijn rekening, zie http://www.europa-

nu.nl/id/vh92jxmyjxhr/subsidies_van_de_europese_unie.

79 Den Ouden, Jacobs en Verheij 2011, p. 223.

8o Van den Brink 2010, p. 70.

81 Zie bijvoorbeeld overweging 16 van het Financieel Reglement van toepassing op de algemene begroting van de Europese Gemeenschappen van 25 juni 2002 ( $P b E G$ 2002, L 248/2).

82 Van den Brink 2009, p. 70.

83 Zie overweging 16 en artikel 54 van het Financieel Reglement van toepassing op de algemene begroting van de Europese Gemeenschappen van 25 juni 2002 (PbEG 2002, L 248/2).

84 Een voorbeeld van een soft law-handeling waar de lidstaten om hebben gevraagd is het hierna te bespreken werkdocument AGR 49533/2002 inzake een kennelijke fout. 
85 Zie daarover Adriaanse 2008, p. 43 en Den Ouden 2009, p. 255-259.

86 Zie bijvoorbeeld HvJ EG 15 december 2005, zaak C-148/o4, Jur. 2005, p. I-11137, r.o. 113 (Unicredito Italiano) .

87 Dit blijkt bijvoorbeeld uit HvJ EG 16 juli 1998, zaak C-298/96, Jur. 1998, p. I4767(Oelmühle); Den Ouden 2009, p. 259.

88 Zie de uitspraak HvJ EG 13 maart 2008, zaak C-383-385/o6, AB 2008, 207 m.nt. W. Den Ouden (ESF-terugvorderingen) waarin deze tendens zichtbaar is. Zie ook Den Ouden 2009, p. 260.

89 Het onderzoek is afgesloten op vrijdag 29 juni 2012.

$90 \mathrm{ABRvS} 11$ oktober 2006, LJN BO1136 r.o. 2.5.1.

91 ABRvS 2 augustus 2008, LJN AY5525 r.o. 2.1.; ABRvS 2 augustus 2008, LJN AY5508 r.o. 2.1.; ABRvS 2 augustus 2008, LJN AY5503 r.o. 2.1.

92 PbEG 1994, C-180/36.

93 Overigens is het verklaarbaar dat de wetgever voor deze weg kiest. Zo kan Nederland er zeker van zijn dat de subsidies voor de Europese Commissie worden verstrekt. Over deze motieven om soft law-handelingen te volgen kom ik hierna nog te spreken. Zie met name paragraaf 3.2.4.3.

94 Working document AGR 49533/2002 on the concept of obvious error according to art 12 of Commission Regulation No. 2419/2001.

95 Werkdocument AGRI/60363/2005-REVI van de Europese Commissie inzake de oppervlakte en de meting van de oppervlakte overeenkomstig de artikelen 23 tot en met 32 van de Verordening 796/2004 van de Europese Commissie.

96 Verordening (EG) nr. 1258/1999 van de Raad van 17 mei 1999 betreffende de financiering van het gemeenschappelijk landbouwbeleid ( $P b E G$ 1999, L 160/03).

97 Dit volgt (nog steeds) uit artikel 175 VWEU.

98 Schöndorf-Haubold 2005, p. 12.

99 Verordening (EG) nr. 1290/2005 van de Raad van 21 juni 2005 betreffende de financiering van het gemeenschappelijk landbouwbeleid.

100 LJN AX8790. Vgl. CBB 3 oktober 2001, $L J N$ AD4706, CBB 16 januari 2002, $L J N$ AD9058, CBB 6 juni 2001, LJN AB2130, CBB 8 augustus 2001, LJN ACo156.

$101 L J N$ BM1599. Vgl. CBB 11 december 2009, LJN BK7274; CBB 11 december 2009, $L J N$ BK7270; CBB 19 februari 2010, LJN BM1825, CBB 20 mei 2011, LJN BQ6205.

102 Verordening 3508/92 van de Raad van 27 november 1992 tot instelling van een geïntegreerd beheers- en controlesysteem voor bepaalde communautaire steunregelingen ( $P b E G$ 1992, L 355/1).

103 Zie overweging 2 van Verordening (EEG) nr. 1765/92 van de Raad van 30 juni 1992, tot instelling van een steunregeling voor producenten van bepaalde akkerbouwgewassen ( $P b E G$ 1995, L 197/2). 
104 Kenmerkend voor EOGFL - G is immers dat het de gemeenschappelijke ordening van de langbouwmarkten tot doel had. Zie paragraaf 3.2.3.

105 Verordening (EG) nr 2419/2001 van de Commissie van 11 december 2001 houdende uitvoeringsbepalingen inzake het bij Verordening (EEG) nr. 3508/92 van de Raad ingestelde geïntegreerde beheers- en controlesysteem voor bepaalde communautaire steunregelingen (PbEG 2001, L 327/11).

106 CBB 29 maart 2007, LJN AX8790, r.o. 5.2.

107 Working document AGR 49533/2002 on the concept of obvious error according tot art 12 of Commission Regulation No. 2419/2001.

108 Via de link: http://mars.jrc.ec.europa.eu/mars/About-us/GeoCAP/DCM.

109 Verordening (EG) Nr. 796/2004 van de Commissie van 21 april 2004 houdende uitvoeringsbepalingen inzake de randvoorwaarden, de modulatie en het geïntegreerd beheersen controlesysteem waarin is voorzien bij Verordening (EG) nr. 1782/2003 van de Raad tot vaststelling van gemeenschappelijke voorschriften voor regelingen inzake rechtstreekse steunverlening in het kader van het gemeenschappelijk landbouwbeleid en tot vaststelling van bepaalde steunregelingen voor landbouwers (PbEG 2004, L 141/18).

110 Vgl. J.E. van den Brink in haar noot bij CBB 27 oktober 2010, $A B$ 2011, 173.

111 Zie hiervoor paragraaf 2.2.2.2

112 Namelijk CBB 27 oktober 2010, $A B$ 2011, 173 m.nt. J.E. van den Brink.

113 CBB 22 juni 2011, LJN BR2912; CBB 21 september 2011, LJN BU1249.

114 Zie artikel 21a lid 2.

115 Het gaat om de volgende zaken: CBB 30 november 2006, LJN AZ3571; CBB 3 juli 2007, $L J N$ BB0115; CBB 6 december 2006, LJN AZ4328; CBB 22 december 2006, LJN AZ5865; CBB 26 juni 2007, $L J N$ BA8565; CBB 20 december 2006, $L J N$ AZ5867; CBB 14 december 2006, LJN AZ5816; CBB 21 maart 2003, LJN AF6914; CBB 30 november 2006, LJN AZ3568; CBB 12 april 2007, $L J N$ BA4862; CBB 26 juni 2007, $L J N$ BA8574.

116 CBB 13 oktober 2006, LJN AZo218; CBB 12 april 2007, LJN AZo218,

117 Verordening (EG), nr. 1254/1999 van de Raad van 17 mei 1999 houdende een gemeenschappelijke ordening der markten in de sector rundvlees (PbEG 1999, L 161/21).

$118 L J N$ AZ3571.

119 In twee uitspraken (CBB 21 maart 2003, $L J N$ AF6914 en CBB 26 juni 2007, $L J N$ BA8574) wordt niet naar deze uitspraak verwezen. Omdat deze uitspraken geen afwijkend beeld laten zien, zal ik deze uitspraken niet apart behandelen. Wel zal ik, waar relevant, naar deze uitspraken verwijzen.

120 Verordening (EG) nr. 1254/1999 van de Raad van 17 mei 1999 houdende een gemeenschappelijke ordening der markten in de sector rundvlees (PbEG 1999, L 161/21).

121 Dit maak ik op uit het feit dat deze Verordening voornamelijk tot doel heeft de markten te stabiliseren en uit artikel 6 van Verordening (EG) nr. 1254/1999.

122 Verordening (EG) nr. 2342/1999 van de Commissie van 28 oktober 1999 tot vaststelling 
van uitvoeringsbepalingen van Verordening (EG) nr. 1254/1999 van de Raad houdende een gemeenschappelijke ordening der markten in de sector rundvlees met betrekking tot de premieregelingen ( $P b E G$ 1999, L 281/30).

123 In de uitspraak is geen verwijzing naar een vindplaats opgenomen, en ook een zoektocht op internet levert geen resultaat op.

124 Dit volgt uit CBB 31 maart 2003, LJN AF6914, r.o. 5 .

125 HvJ EG 13 december 1989, zaak C-322/88, Jur. 1989, p. I-4407 r.o. 8 (Grimaldi).

126 Vgl. CBB 21 maart 2003, LJN AF6914. Zie voor de situatie waarin het CBB niet met de Interpretatienota's rekening houdt waar het bestuur dat ook niet doet CBB 26 juni 2007, LJN BA8574, r.o. 5.2.

127 Zie paragraaf 2.2.2.4.

128 HvJ EG 13 december 1989, zaak C-322/88, Jur. 1989, p. I-4407 r.o. 8 (Grimaldi). Zie ook HvJ EG 13 maart 2003, zaak C-207/01, Jur. 2003, p. I-8875, r.o. 41 (Altair Chimica).

129 Dit ligt anders als de Commissie er expliciet om vraagt de soft law-handeling in een nationale regeling of toelichting neer te leggen, of om bij het maken daarvan met de soft lawhandeling rekening te houden. Zie paragraaf 2.2.2.1.

130 Verordening 3508/92 van de Raad van 27 november 1992 tot instelling van een geïntegreerd beheers- en controlesysteem voor bepaalde communautaire steunregelingen ( $P b E G$ 1992, L 355/1).

131 Zie overweging 2 van Verordening (EEG) nr. 1765/92 van de Raad van 30 juni 1992, tot instelling van een steunregeling voor producenten van bepaalde akkerbouwgewassen $(P b E G$ 1995, L 197/2).

132 Kenmerkend voor EOGFL - G is immers dat het de gemeenschappelijke ordening van de langbouwmarkten tot doel had. Zie paragraaf 3.2.3.

133 Verordening (EG) nr 2419/2001 van de Commissie van 11 december 2001 houdende uitvoeringsbepalingen inzake het bij Verordening (EEG) nr. 3508/92 van de Raad ingestelde geïntegreerde beheers- en controlesysteem voor bepaalde communautaire steunregelingen (PbEG 2001, L 327/11).

134 CBB 29 maart 2007, LJN AX8790, r.o. 5.2.

135 Working document AGR 49533/2002 on the concept of obvious error according tot art 12 of Commission Regulation No. 2419/2001.

136 Via de link: http://mars.jrc.ec.europa.eu/mars/About-us/GeoCAP/DCM.

137 Verordening (EG) Nr. 796/2004 van de Commissie van 21 april 2004 houdende uitvoeringsbepalingen inzake de randvoorwaarden, de modulatie en het geïntegreerd beheersen controlesysteem waarin is voorzien bij Verordening (EG) nr. 1782/2003 van de Raad tot vaststelling van gemeenschappelijke voorschriften voor regelingen inzake rechtstreekse steunverlening in het kader van het gemeenschappelijk landbouwbeleid en tot vaststelling van bepaalde steunregelingen voor landbouwers ( $P b E G$ 2004, L 141/18).

138 Vgl. J.E. van den Brink in haar noot bij CBB 27 oktober 2010, AB 2011, 173.

139 Zie hiervoor paragraaf 2.2.2.2 
140 Zie artikel 21a lid 2.

141 Verordening (EG) nr. 1254/1999 van de Raad van 17 mei 1999 houdende een gemeenschappelijke ordening der markten in de sector rundvlees ( $P b E G$ 1999, L 161/21).

142 Dit maak ik op uit het feit dat deze Verordening voornamelijk tot doel heeft de markten te stabiliseren en uit artikel 6 van Verordening (EG) nr. 1254/1999.

143 Verordening (EG) nr. 2342/1999 van de Commissie van 28 oktober 1999 tot vaststelling van uitvoeringsbepalingen van Verordening (EG) nr. 1254/1999 van de Raad houdende een gemeenschappelijke ordening der markten in de sector rundvlees met betrekking tot de premieregelingen (PbEG 1999, L 281/30).

$\mathbf{1 4 4}$ In de uitspraak is geen verwijzing naar een vindplaats opgenomen, en ook een zoektocht op internet levert geen resultaat op.

145 Dit volgt uit CBB 31 maart 2003, LJN AF6914, r.o. 5.

146 HvJ EG 13 december 1989, zaak C-322/88, Jur. 1989, p. I-4407 r.o. 8 (Grimaldi).

147 Vgl. CBB 21 maart 2003, LJN AF6914. Zie voor de situatie waarin het CBB niet met de Interpretatienota's rekening houdt waar het bestuur dat ook niet doet CBB 26 juni 2007, LJN BA8574, r.o. 5.2.

148 Verhey 1989, p. 189.

149 Of definities die daar op lijken, (zo dient volgens Van der Vlies (1984) ingrijpend overheidsoptreden op een wettelijke grondslag te berusten, en gaat het volgens anderen om overheidsoptreden dat inbreuk maakt op de vrijheid en het eigendom van burgers (Van Wijk/Konijnenbelt en Van Male 2011, p. 34 en 35; Verheij 1989, p. 189); Zie voor een overzicht Voermans 2011, p. 7.

150 Zie Voermans 2011.

151 Vgl. Scheltema 1996, p. 1358.

152 Vgl. Voermans 2011, p. 77. De begrippen input- en output- legitimiteit vinden hun oorsprong in het werk van Scharpf 1999.

153 Zie voor een bespreking van input-legitimiteit Scharpf 1999, p. 7-10.

154 "Throughput' legitimacy concentrates on what goes on inside the 'black box' of EU governance, in the space between the political input and the policy output, aldus Vivien Schmidt. Zie Schmidt 2012, p. 4.

155 Scharpf 1999, p. 11; Voermans 2011, p. 76.

156 Oldenziel 1998, p. 244.

Van Wijk e.a. 2008, p. 37; Scheltema 1996, p. 1358.

$\mathbf{1 5 7}$ Een soft law-handeling is zo bezien vergelijkbaar met de Nederlandse beleidsregel. Ook de Nederlandse beleidsregel mag niet zelfstandig verplichtingen in het leven roepen; als dat wel gebeurt kan de beleidsregel niet door de legaliteitsbeugel. Zie Van Wijk/Konijnenbelt en Van Male 2011, p. 34 en 35.

Als ervan uit zou worden gegaan dat elk overheidsoptreden op een wettelijke regel moet berusten, vormt soft law wel een probleem. Zie bijvoorbeeld : Damen 1987, p. 315 . 
158 Zie bijvoorbeeld HvJEU 16 juni 1993, zaak C-325/91, Jur. 1993, p. I-3283, r.o. 22 en 23 (Frankrijk/Commissie).

159 Zie over deze problematiek het interessante artikel 'Legitimacy in the multilevel European polity', waarin Scharpf de relatie tussen de EU en de lidstaten beschouwt in het licht van legitimiteit. Scharpf 2009, p. 173-204.

160 Dit beginsel is neergelegd in artikel 5 VWEU.

161 De Europese Unie kent overigens een eigen legaliteitsbeginsel dat op het attributiebeginsel is gebaseerd.

Het Europese legaliteitsbeginsel heeft echter, anders dan het Nederlandse legaliteitsbeginsel niet in de eerste plaats de bescherming van burgers ten doel, maar dient het evenwicht tussen de Europese instellingen te bewaren. Zie Verhoeven 2011, p. 157; Voermans 2011, p. 32; Blumann en Dubouis 2010, p. 401-403.

162 Vgl. Schmidt 2012, p. 18.

163 Zie bijvoorbeeld De Búrca 2011, p. 349; Collignon 2006, p. 75-85; Dammers 2010, p. 34 en 35

164 Vgl. Scott 2011 p, 344.

165 Mortelmans 1979, p. 17.

166 Jans, Prechal en Widdershoven 2011, p. 35.

167 Voermans 2010, p. 178.

168 HvJ EG 20 maart 1997, zaak C-57/95, Jur. 1997, p. I-1640 (Frankrijk/Commissie). Zie paragraaf 2.2.1

169 Zie paragraaf 2.2.1.

170 Vgl. Lefevre 2011, p. 819.

171 HvJ EG 5 mei 1998, zaak C-180/96, p. I-2265, r.o. 28 (Verenigd Koninkrijk/Commissie). Zie ook HvJ EG 15 oktober 1997, zaak C-443/97. r.o. 34 (Spanje Commissie) en HvJ EG 27 september 1988, zaak 114/86, Jur. 1988, p. 5289, r.o. 13 (Verenigd Koninkrijk/Commissie).

172 HvJ EG 8 april 1992, zaak C-94/91, Jur. 1992, p. I-2765, r.o. 17 (Wagner); HvJ EG 12 januari 2006, zaak C-311/04, Jur. 2006, p. I-609, r.o. 25. (Algemene Scheepsagentuur DordrechtI).

173 De Grimaldi-uitspraak (HvJ EG 13 december 1989, zaak C-322/88, Jur. 1989, p. I-4407 r.o. 8 laat echter een ander beeld zien. In deze uitspraak, waarin een interpretatievraag aan het Hof wordt gesteld, overweegt het Hof 'dat artikel 177 EEG-Verdrag (thans artikel 267 VWEU) aan het Hof de bevoegdheid verleent bij wege van prejudiciële beslissing uitspraak te doen over de geldigheid en de uitlegging van de door de instellingen van de Gemeenschap verrichte handelingen, zonder enige uitzondering'. Volgens Scott betekent deze jurisprudentie niet zonder meer dat de weg naar geldigheidsvragen openstaat (Scott 2011, p. 346 noot 84).

174 Zie bijvoorbeeld HvJ EG 6 april 2000, zaak C-443/o97, Jur. 2000, p. I-2415, r.o. 33 (Spanje/Commissie).

175 Zie bijvoorbeeld HvJ EG 15 januari 2002, zaak C-171/oo, Jur. 2002, p. I-451, r.o. 35 (Libéros/Commissie); HvJ EG 28 juni 2005, gevoegde zaken C-189/02 P, C-202/02 P, C- 
205/o2 P tot en met C-208/o2 P en C-213/o2 P Jur. 2005, p. I-5425, (Dansk Rørindustri).

$\mathbf{1 7 6}$ Zie artikel 277 VWEU.

177 Ambtenbrink en Vedder 2010, p. 249.

178 Scott 2011, p. 344-345.

179 Gedacht kan bijvoorbeeld worden aan de situatie waarin een Europese subsidie onder verwijzing naar een administratieve soft law-handeling wordt afgewezen door een nationaal bestuursorgaan. Voor de nationale rechter zou de particulier de afwijzing kunnen aanvechten door te betogen dat de soft law-handeling in strijd is met unierechtelijke hard law. De nationale rechter zal dan een oordeel moeten vellen over de inhoud van de hard law-bepaling, terwijl over de verenigbaarheid van de soft law-handeling met de hard law-bepaling geen duidelijkheid wordt geschapen. De particulier kan zeer waarschijnlijk niet bij het Hof terecht. Immers, tegen een handeling van een nationaal bestuursorgaan en tegen Europese soft lawhandelingen staat de weg van artikel 263 niet open (tenzij sprake is van verkapte hard law) en van rechtstreekse en individuele geraaktheid door de hard law-bepaling zal niet snel sprake zijn.

180 Zie paragraaf 3.4 .

181 Senden 1997, p. 234.

182 Uitzonderingen zijn de gedelegeerde handelingen en de uitvoeringshandelingen ex artikel 290 en 291 VWEU. Zie daarover Voermans 2010, p. 166, 167.

183 Zie artikel 288 VWEU.

184 Als de soft law-handeling vrijwillig op nationaal niveau wordt gevolgd, moet de gedragslijn op nationaal niveau wel in een beleidsregel of in wet- of regelgeving worden neergelegd om rechtszekerheid te garanderen.

185 Lefevre 2004, p. 810, 811; Luijendijk en Senden 2011, p. 318.

186 Stefan 2012, p. 50 en 51.

187 Scheltema 2011, p. 1435 .

188 Vgl. Scheltema 2011, p. 1434.

189 Resolutie van het Europees Parlement van 4 september 2007 over de institutionele en juridische gevolgen van het gebruik van 'soft-law' instrumenten, A6-0259/2007.

190 Zie daarover Lefevre 2011, p. 819.

191 Voermans 2008, p. 71; Dammers 2007, p. 26; Ambtenbrink en Vedder 2010, p. 84.

192 Voermans 2008, p. 80, Ambtenbrink en Vedder 2010, p. 84.

193 Ook Lefevre denkt aan deze optie, maar komt tot de conclusie dat betrokkenheid van de lidstaten bij de voorbereiding van soft law niet wenselijk is. (Daar kom ik (kort) op terug in paragraaf 5.1.4.) Zie Lefevre 2004, p. 820 en 812.

194 Dus aan het einde van de procedure, als het voorstel langs het parlement is geweest.

195 De lidstaat loopt dan overigens wel het risico dat hij in een procedure voor het Hof in de 
problemen komt, namelijk als het Hof dezelfde interpretatie geeft aan een bepaling als de interpretatie die in de soft law-handeling door de Commissie is gesuggereerd. Daarom is het voor lidstaten van belang zich in de voorbereidingsfase actief op te stellen en mee te onderhandelen over de inhoud van de soft law-handeling.

196 Voermans 2008 p. 76 en 77; Scheltema 2011, p. 1435.

197 Dammers 2007, p. 43.

198 Ook volgens Luijendijk en Senden moet over deze mogelijkheid worden nagedacht (2011, p. 250).

199 Zie paragraaf 4.3.1.

200 Zo wordt de Leiden Expert Group on State Aid die cursussen verzorgd aan nationale rechters met het oog op toepassing van het Europese staatssteunrecht, door de Europese Commissie financieel ondersteund. Zie het nieuwsbericht op de website van de Universiteit Leiden: http://law.leidenuniv.nl/legsa/nieuws/paul-adriaanse-en-willemien-den-oudenkrijgen-eu-subsidie-voor-legsa-project-.html, en voor meer informatie over LEGSA http://law.leidenuniv.nl/legsa/.

201 Ambtenbrink en Vedder 2010, p. 86.

202 Voermans 2004, p. 80.

203 Zie anders: Lefevre 2004, p. 821. Volgens hem zou een uitbreiding van het comitologiesysteem naar soft law-handelingen de scheiding der machten tussen de Europese instellingen doorkruisen. Het is overigens verwonderlijk dat hij over een scheiding der machten spreekt, omdat in het algemeen wordt aangenomen dat deze op Europees niveau niet aanwezig is. In plaats van scheiding der machten wordt daarom gesproken over 'institutioneel evenwicht'. Zie daarvoor Dammers 2008, p. 16. Ik ga er daarom vanuit dat Lefevre met een scheiding der machten in dit geval hetzelfde bedoelt als een institutioneel evenwicht.

204 Voorstander hiervan is ook Scheltema, zie Scheltema 1996, p. 1359.

205 Resolutie van het Europees Parlement van 4 september 2007 over de institutionele en juridische gevolgen van het gebruik van 'soft-law' instrumenten, A6-0259/2007.

206 Zie daarover Lefevre 2011, p. 819.

207 Voermans 2008, p. 71; Dammers 2007, p. 26; Ambtenbrink en Vedder 2010, p. 84.

208 Voermans 2008, p. 80, Ambtenbrink en Vedder 2010, p. 84.

209 Ook Lefevre denkt aan deze optie, maar komt tot de conclusie dat betrokkenheid van de lidstaten bij de voorbereiding van soft law niet wenselijk is. (Daar kom ik (kort) op terug in paragraaf 5.1.4.) Zie Lefevre 2004, p. 820 en 812.

$\mathbf{2 1 0}$ Dus aan het einde van de procedure, als het voorstel langs het parlement is geweest.

211 De lidstaat loopt dan overigens wel het risico dat hij in een procedure voor het Hof in de problemen komt, namelijk als het Hof dezelfde interpretatie geeft aan een bepaling als de interpretatie die in de soft law-handeling door de Commissie is gesuggereerd. Daarom is het voor lidstaten van belang zich in de voorbereidingsfase actief op te stellen en mee te onderhandelen over de inhoud van de soft law-handeling.

212 Voermans 2008 p. 76 en 77; Scheltema 2011, p. 1435. 
213 Dammers 2007, p. 43.

214 Ook volgens Luijendijk en Senden moet over deze mogelijkheid worden nagedacht (2011, p. 250).

$\mathbf{2 1 5}$ Zie paragraaf $4 \cdot 3.1$.

216 Zo wordt de Leiden Expert Group on State Aid die cursussen verzorgd aan nationale rechters met het oog op toepassing van het Europese staatssteunrecht, door de Europese Commissie financieel ondersteund. Zie het nieuwsbericht op de website van de Universiteit Leiden: http://law.leidenuniv.nl/legsa/nieuws/paul-adriaanse-en-willemien-den-oudenkrijgen-eu-subsidie-voor-legsa-project-.html, en voor meer informatie over LEGSA http://law.leidenuniv.nl/legsa/. 